In cooperation with the Ohio Department of Health

\title{
Preliminary Investigation of Wastewater-Related Contaminants near Home Sewage Treatment Systems in Ohio
}
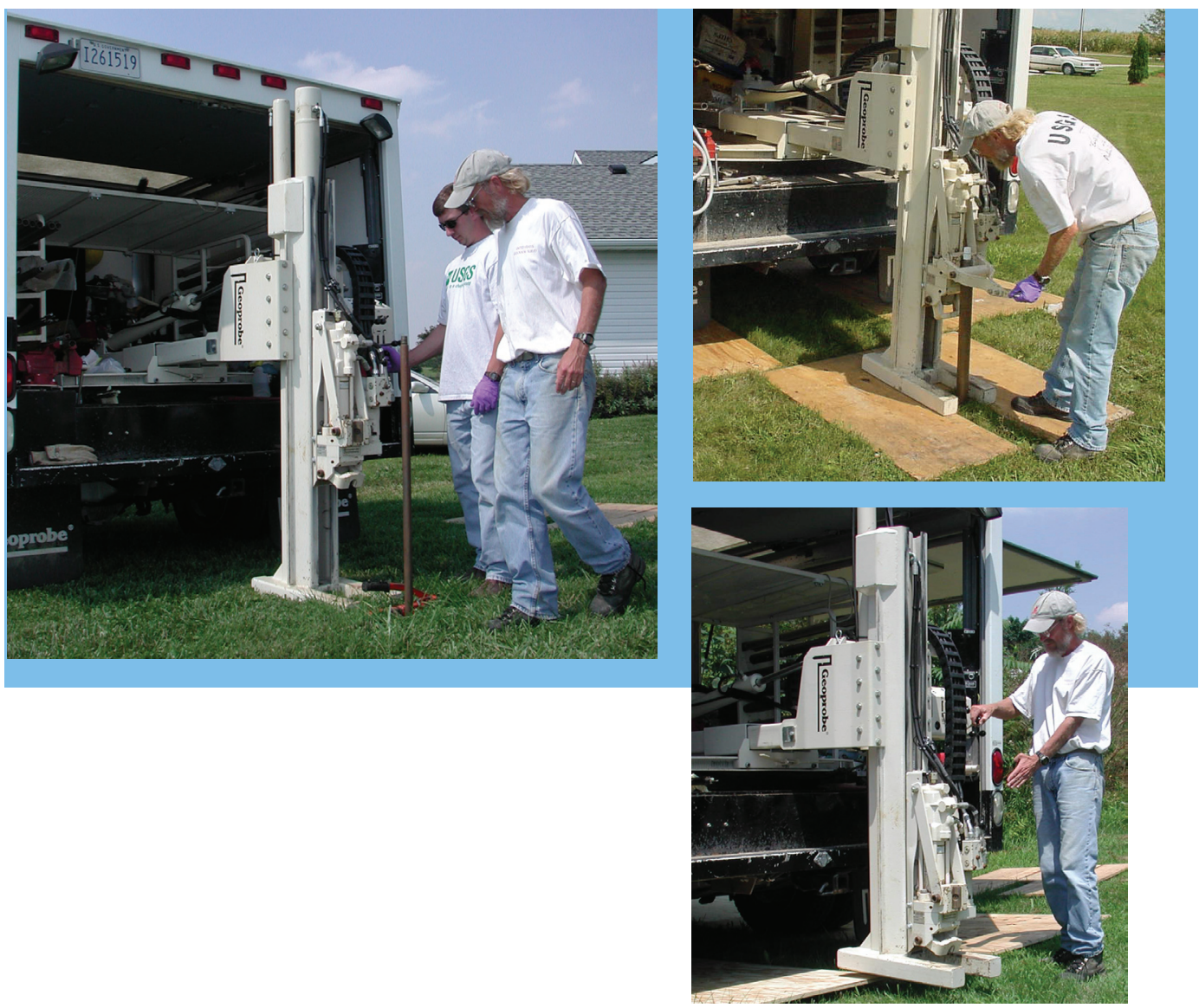

Open-File Report 2005-1282 
Cover images: USGS employees installing piezometers (photos by D.H. Dumouchelle, U.S.Geological Survey). 


\section{Preliminary Investigation of Wastewater- Related Contaminants near Home Sewage Treatment Systems in Ohio}

By D.H. Dumouchelle and D.M. Stoeckel

In cooperation with the Ohio Department of Health

Open-File Report 2005-1282 


\section{U.S. Department of the Interior \\ Gale A. Norton, Secretary \\ U.S. Geological Survey \\ P. Patrick Leahy, Acting Director}

U.S. Geological Survey, Reston, Virginia: 2005

For sale by U.S. Geological Survey, Information Services
Box 25286, Denver Federal Center
Denver, CO 80225
For more information about the USGS and its products:
Telephone: 1-888-ASK-USGS
World Wide Web: http://www.usgs.gov/

\footnotetext{
Any use of trade, product, or firm names in this publication is for descriptive purposes only and does not imply endorsement by the U.S. Government.

Although this report is in the public domain, permission must be secured from the individual copyright owners to reproduce any copyrighted materials contained within this report.

Suggested citation:

Dumouchelle, D.H., Stoeckel, D.M., 2005, Preliminary investigation of wastewater-related contaminants near home sewage treatment systems in Ohio: U.S. Geological Survey Open-File Report 2005-1282, 31 p.
} 


\section{Contents}

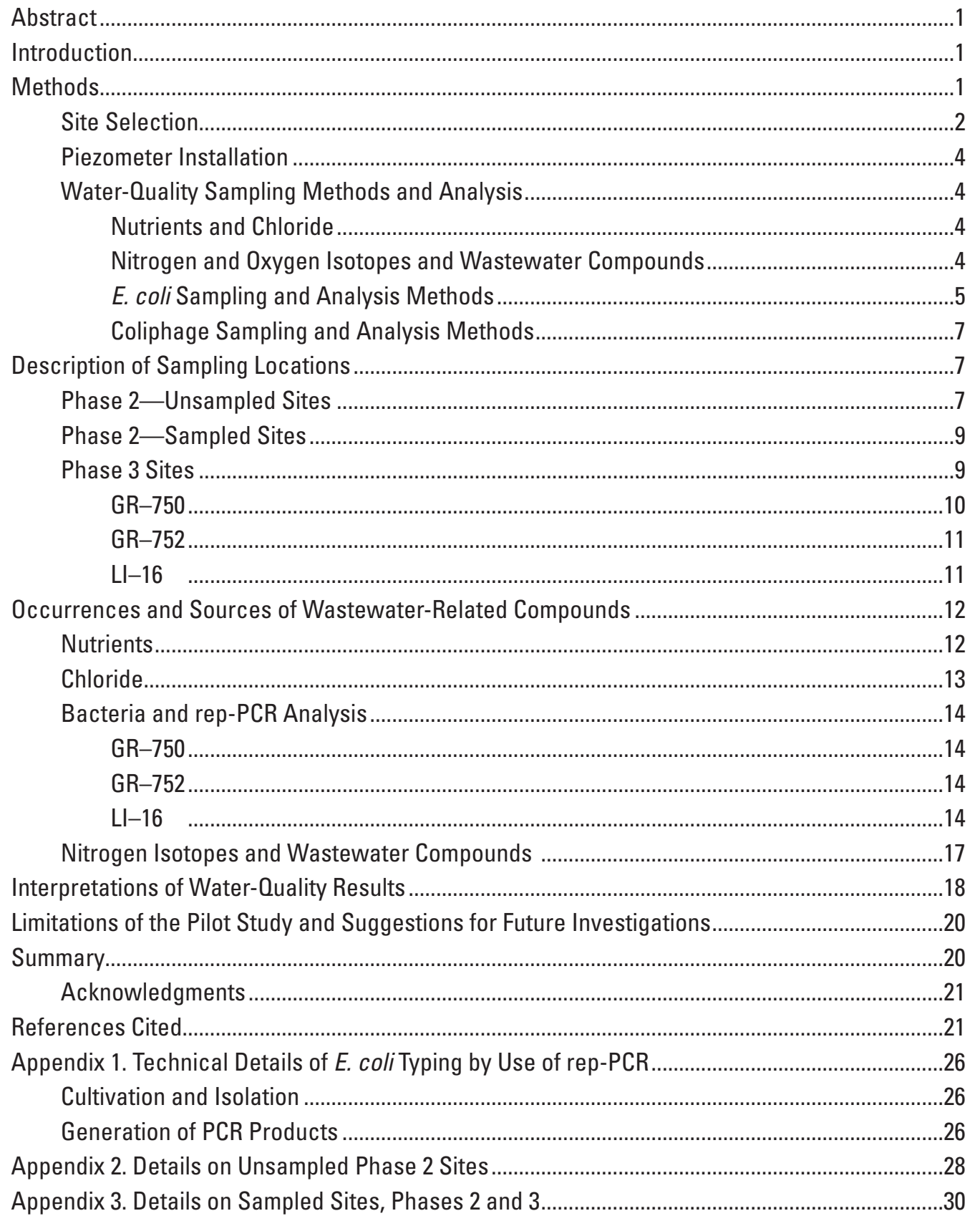




\section{Figures}

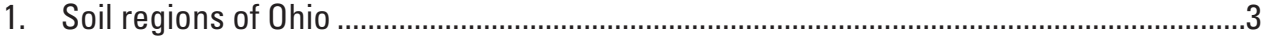

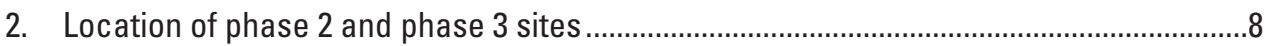

3. Schematic of septic system and piezometers at site GR-750 in Greene County, Ohio ................................................................................................10

4. Schematic of septic system and piezometers at site GR-752 in Greene County, Ohio ................................................................................................11

5. Schematic of septic system and piezometers at site LI-16

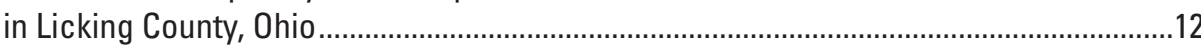

6. Example of results of rep-PCR analysis showing six isolates and multiple measurements of a single isolate, demonstrating the reproducibility of results

\section{Tables}

1. Wastewater-method compound names, USGS National Water Quality Laboratory reporting limits, and possible compound uses................................................

2. Counties, soil regions, and numbers of sites investigated in Ohio .....................................

3. Location, rainfall, and screen-interval data for sites with piezometers that could not be sampled in Ohio

4. Locations, rainfall, screen intervals, and samples collected for Phase 2 sites in Ohio

5. Specific conductance and chloride and nutrient concentrations in ground-water samples from phase 2 and phase 3 piezometers at various sites in Ohio.

6. Escherichia coli and coliphage anaylses of ground-water samples from phase 2 and phase 3 piezometers at various sites in Ohio.

7. Sites and characteristics of isolates in those Operational Taxonomic Units found from more than one source.

8. Nitrogen and oxygen isotope ratios in ground-water samples from phase 3 piezometers at sites GR-750 and GR-752, Greene County, Ohio

9. Wastewater-compound concentrations in ground-water samples from phase 3 piezometers at GR-750, Greene County, Ohio

10. Wastewater-compound concentrations in ground-water samples from phase 3 piezometers at GR-752, Greene County, Ohio

11. Summary of water-quality and E. coli data indicating the movement of untreated waste water from home sewage treatment systems to adjacent piezometers. 


\section{Conversion Factors and Abbreviations}

\begin{tabular}{lcl}
\hline Multiply & By & To obtain \\
\hline & Length & \\
\hline inch (in.) & 2.54 & centimeter $(\mathrm{cm})$ \\
inch (in.) & 25.4 & millimeter $(\mathrm{mm})$ \\
foot (ft) & 0.3048 & meter $(\mathrm{m})$ \\
mile (mi) & 1.609 & kilometer $(\mathrm{km})$ \\
\hline \multicolumn{3}{c}{ Volume } \\
\hline gallon (gal) & 0.003785 & cubic meter $\left(\mathrm{m}^{3}\right)$ \\
\hline & Flow rate \\
\hline inches per hour (in/h) & 0.0254 & meter per hour $(\mathrm{m} / \mathrm{h})$ \\
inches per year (in/yr) & 25.4 & millimeter per year $(\mathrm{mm} / \mathrm{yr})$ \\
million gallons per day (Mgal/d) & 0.04381 & cubic meter per second $\left(\mathrm{m}^{3} / \mathrm{s}\right)$ \\
\hline
\end{tabular}

Temperature in degrees Celsius $\left({ }^{\circ} \mathrm{C}\right)$ may be converted to degrees Fahrenheit $\left({ }^{\circ} \mathrm{F}\right)$ as follows:

$$
{ }^{\circ} \mathrm{F}=\left(1.8 x^{\circ} \mathrm{C}\right)+32
$$

Temperature in degrees Fahrenheit $\left({ }^{\circ} \mathrm{F}\right)$ may be converted to degrees Celsius $\left({ }^{\circ} \mathrm{C}\right)$ as follows:

$$
{ }^{\circ} \mathrm{C}=\left({ }^{\circ} \mathrm{F}-32\right) / 1.8
$$

Specific conductance is given in microsiemens per centimeter at 25 degrees Celsius $(\mu \mathrm{S} / \mathrm{cm}$ at $\left.25^{\circ} \mathrm{C}\right)$.

Small sample volumes are reported in milliliters $(\mathrm{mL})$ and microliters $(\mu \mathrm{L})$. Concentrations of chemical constituents in water are given either in milligrams per liter $(\mathrm{mg} / \mathrm{L})$, micrograms per liter $(\mu \mathrm{g} / \mathrm{L})$, or nanograms per microliter $(\mathrm{ng} / \mu \mathrm{L})$. 


\title{
Preliminary Investigations of Wastewater-Related Contaminants Near Home Sewage Treatment Systems in Ohio
}

\author{
By D.H. Dumouchelle and D.M. Stoeckel
}

\section{Abstract}

The U.S. Geological Survey, in cooperation with the Ohio Department of Health, investigated the occurrence and sources of wastewater-related contaminants near home sewage treatment systems (HSTS). Piezometers were installed near active leach lines at 20 sites among 9 Ohio counties. Despite an unusually wet year, water samples could not be obtained from piezometers at eight sites; at 5 of the other 12 sites, water could be obtained from only one piezometer. Water samples from the piezometers were analyzed for nutrients, chloride, and Escherichia coli (E. coli) bacteria to determine whether untreated wastewater was migrating away from the systems. Additional water samples were collected at two sites and analyzed for nitrogen isotopes and wastewater compounds. At three sites, bacteria were analyzed by means of repetitive DNA element polymerase chain reaction (repPCR) to indicate the source of the bacteria.

Nitrate concentrations ranged from 0.2 to 25.9 milligrams per liter $(\mathrm{mg} / \mathrm{L})$ but exceeded $10 \mathrm{mg} / \mathrm{L}$, an indication of wastewater influence, at only two sites. Chloride concentrations ranged from 18.4 to $1,150 \mathrm{mg} / \mathrm{L}$; concentrations in excess of $200 \mathrm{mg} / \mathrm{L}$, which may indicate some influence of wastewater, were found at five sites. E. coli were found in water from piezometers at three sites. Water samples from two of these $E$. coli $i$-positive sites were analyzed for nitrogen isotopes and wastewater compounds. The nitrate concentrations were too low for accurate isotopic analysis; however, various wastewater compounds were found in samples from both sites, indicating wastewater movement. The rep-PCR process provided evidence of a linkage between the bacteria from HSTS to bacteria found in piezometers at several sites and to a curtain drain. The results of the water quality and rep-PCR analysis indicate that untreated wastewater can move laterally several feet from HSTS to the piezometers.

\section{Introduction}

A properly designed and operating home sewage treatment system (HSTS) is capable of removing suspended solids, biodegradable organic compounds, and fecal bacteria. If treatment is incomplete, contaminants can reach ground water or surface water. Many HSTSs rely, at least in part, on soils to treat and filter wastewater. Poor soil drainage, high seasonal water tables, or shallow bedrock can contribute to the failure of an HSTS to completely treat wastewater. An assessment of Ohio soils indicates that less than 10 percent are suitable for an HSTS using traditional leach lines (Mancl and Slater, 2001).

The U. S. Geological Survey (USGS), in cooperation with the Ohio Department of Health (ODH), designed a pilot study to obtain a better understanding of the quality of water exiting HSTSs and investigate the usefulness of genetic fingerprinting analysis in determining the source of any fecal-related bacteria found. During the summer and fall 2003 and early winter 2004, the USGS installed and sampled piezometers near HSTSs. These systems are intended to treat sewage, so failure would be defined by indications of untreated effluent in the soils surrounding the leach field. This report is a detailed description of the methods used in and the results derived from the USGS-ODH study.

\section{Methods}

This study was done in three phases-site selection, initial sampling, and intensive sampling at select sites. During Phase 1 geographic information system (GIS) data sets of soils were analyzed to select a number of potential sites for phase 2 work. During phase 2, ground water was sampled at selected sites by use of piezometers installed within a few feet of a leach line. Ground water was sampled for nutrients, chloride, and Escherichia coli (E. coli) bacteria concentrations. Sites at which $E$. coli were found were considered for inclusion in phase 3 . In phase 3 , done at two sites, additional piezometers 
were installed and the same constituents as in phase 2, plus nitrogen isotopes and wastewater compounds, were sampled for. Genetic fingerprinting of $E$. coli, using repetitive DNA element polymerase chain reaction (rep-PCR), was done on $E$. coli samples from both the HSTS and piezometers to indicate the source of $E$. coli cultivated from water from the piezometers.

A typical site consists of a septic tank that discharges to a leach field through a diverter box. (Some examples are shown in figs. 3-5, in the middle of the report.) The majority of the HSTSs are designed to move fluids by way of gravity. The leach field generally has two sets of leach lines, frequently parallel. The lines are perforated plastic pipe buried in gravel in a trench; the trench is backfilled with soil and planted with grass. The diverter box consists of a small concrete box that has three plastic pipes. One pipe comes from the septic tank and discharges into the box; each of the other pipes, set at approximately the same depth as the first pipe, discharges to a set of leach lines. Flow can be diverted from one set of leach lines to the other by use of an elbow. The elbow, placed on one of the leach-line pipes, will point up-effectively raising the level of the opening to one of the lines and thereby limiting septic-tank discharge to one set of leach lines. In addition, many sites have perimeter drains, also called curtain drains. These drains, similar in construction to the leach lines, are not connected to the HSTS. The drains are intended to intercept local ground-water flow, thereby improving the drainage of the leach field. Curtain drains frequently discharge, by way of gravity, to a nearby roadside ditch.

\section{Site Selection}

Sites were selected by two methods. The initial, more rigorous method, included the use of county records, GIS datasets, and site visits. The second method, used to supplement sites from the first method, was a generic request for sites in selected areas. Sites that were volunteered were then reviewed for suitable soils, system design, and site access. Of the 20 sites used in this study, 15 were selected with the initial method, and 5 were selected by use of the second method.

The counties in Ohio initially targeted for study by $\mathrm{ODH}$ were (1) well documented in terms of county health department HSTS construction records and (2) represented a range of soil regions (fig. 1). These records, consisting of about 300 to 800 addresses per county, provided a list of potential sampling sites in a given county. The GIS-based selection process was designed to reduce these lists to about 30 to 40 sites per soil region. The sites were then visited to confirm suitability for the study.

The GIS data for the soils in most of the selected counties were obtained from the Ohio Department of Natural Resources (1975-87). Soil-characteristics data were obtained from the U.S. Department of Agriculture (1997). For Greene County, the GIS site selection used the Soil Survey Geographic Database (SSURGO) (U.S. Department of Agriculture, 2000).
The preferred sites were in soils deemed unsuitable for septic systems (Mancl and Slater, 2001). Three soil variables_-permeability, depth to seasonal water table (soil water), and depth to bedrock or impermeable pan-were used to identify soils unsuitable for HSTSs. The GIS soils datasets had ratings for each variable. A rating of "moderate" indicates soil limitations for septic systems, but construction modifications, such as increasing the length of leach lines for low permeability or using a mound system for high seasonal water table, may improve system performance. A rating of "severe" indicates that the soil limitations are too difficult or expensive to overcome. The following table lists a selected range of soil limitations for HSTS as defined by Brady and Weil (1999).

\begin{tabular}{|c|c|c|}
\hline $\begin{array}{c}\text { Soil } \\
\text { variable }\end{array}$ & $\begin{array}{l}\text { Moderate } \\
\text { limitations }\end{array}$ & $\begin{array}{c}\text { Severe } \\
\text { limitations }\end{array}$ \\
\hline Permeability & $0.6-2.00 \mathrm{in} / \mathrm{h}$ & Less than $0.60 \mathrm{in} / \mathrm{h}$ \\
\hline $\begin{array}{l}\text { Depth to -seasonal } \\
\text { water table }\end{array}$ & 4-6 ft below surface & $\begin{array}{l}\text { Less than } 4 \mathrm{ft} \text { below } \\
\text { surface }\end{array}$ \\
\hline Depth to bedrock & $\begin{array}{l}\text { 40-72 in. below } \\
\text { surface }\end{array}$ & $\begin{array}{l}\text { Less than } 40 \text { in. below } \\
\text { surface }\end{array}$ \\
\hline
\end{tabular}

Soils with slight limitations on HSTS have permeabilites between 2 and $6 \mathrm{in} / \mathrm{hr}$, and (or) seasonal water tables at greater than $6 \mathrm{ft}$ in depth, and (or) bedrock deeper than 73 in. Only sites with soils categorized as having moderate and (or) severe limitations for each of the three variables were selected during the GIS-based screening process.

The address lists from each county included some or all of the following information: street address, township, city, zip code, existence of curtain (or perimeter) drain, type of HSTS, and installation date. The geographic locations of the addresses with leach-line or leach-bed HSTS were determined from the address and the U.S. Bureau of the Census (2000) GIS roads datasets.

A polygon coverage was generated for each of the soil variables. Because a particular soil type typically has different properties at different depths (horizons), only the data for the 24-in. depth horizon was evaluated; 24 in. is the common installation depth for HSTS leach lines. Next, a point coverage of the addresses was overlain on the polygon soil coverages so that the HSTS suitability rating for each address could be determined.

To allow for scale effects between the different data sets, a circle with a radius of about $500 \mathrm{ft}$ was evaluated around each address point. At each address, the percentages of each soil type and variable were computed. About 30 to 40 sites were selected on the frequency of moderate and (or) severe soil variable ratings and the amount of such soils in the area of the address.

The final determining factor in site selection was homeowner permission and access for a drilling rig to the leach field. These final factors posed the greatest difficulty in selecting sites. At many sites, homeowners were willing and interested in the investigation, but the leach field was inaccessible for the rig; at other properties, the homeowner could 

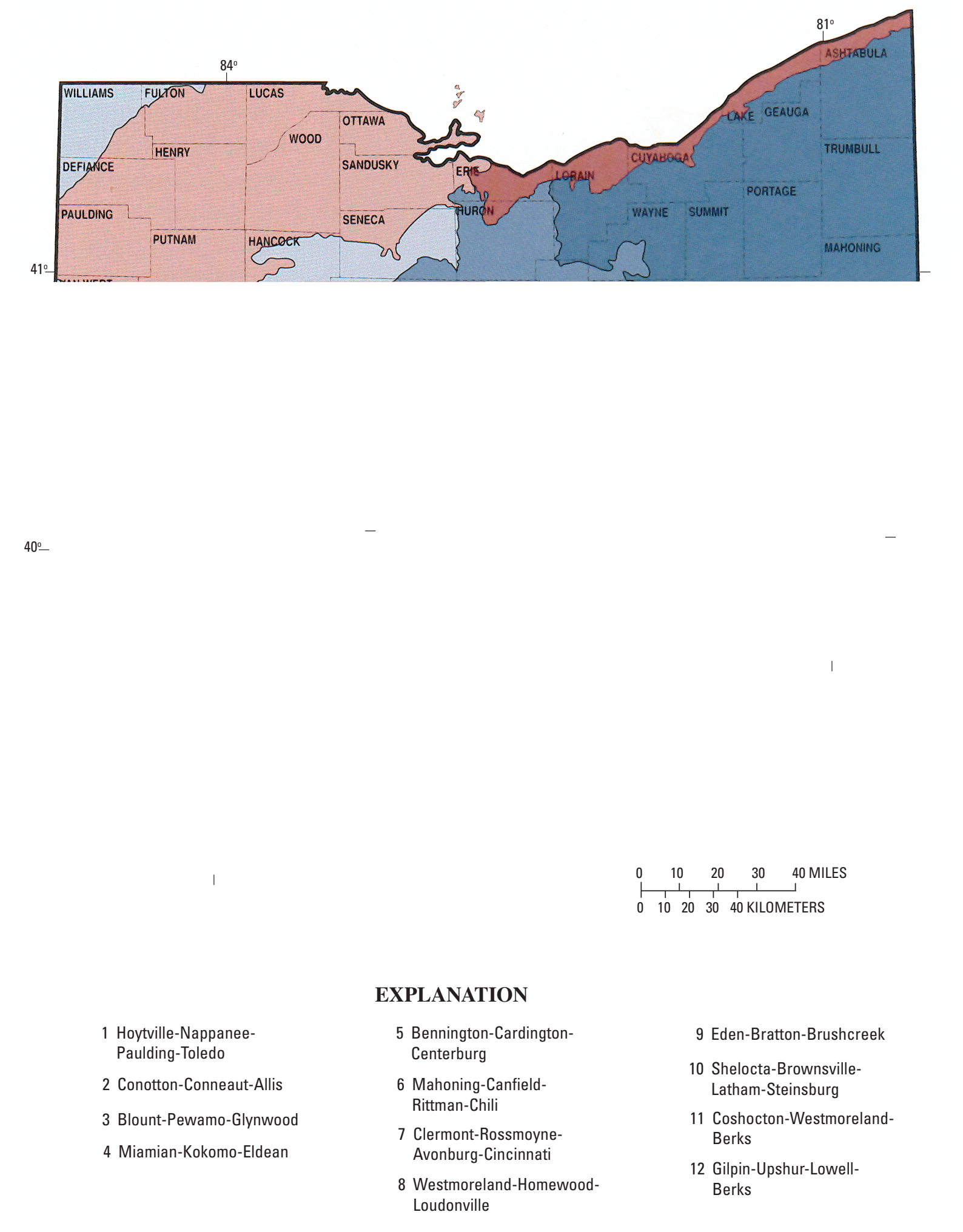

Figure 1. Soil regions of Ohio. 
not be reached for permission. As a result, only 15 sites were selected by means of the GIS screening approach. An effort to locate additional sites used a second, less rigorous approach which included "cold calls" at some addresses and visiting sites volunteered from a variety of professional contacts. These sites were checked for appropriate soil classifications, installation records, and accessibility. Five usable sites were selected in this manner.

\section{Piezometer Installation}

Upon arrival at a site, study investigators visually examined the leach field and surrounding area to determine slopes and locate leach lines. The diverter box was checked to determine the active leach line. A tile probe was used to confirm the location of the leach lines and curtain drain, if present. Prior to installation, the piezometers and related equipment were pressure washed with soap and water, rinsed with deionized water, then sprayed with isopropyl alcohol. If the weather was dry and the winds calm, the alcohol rinse was flamed off; in all cases, there was a final rinse of sterile deionized water. The interior and exterior of the piezometers were cleaned and sterilized. Clean and sterile equipment was handled with clean gloves. Phase 2 piezometers were placed between 3 and $4 \mathrm{ft}$ from an active leach line, downslope from the line if possible. Phase 3 piezometers were placed at numerous distances from an active leach line, both inside and outside the curtain drain.

The 1-in.-diameter piezometers were driven with either a truck-mounted rig or with a manual weight. To avoid clogging the stainless-steel screens during installation, a steel drive casing was used. The drive casing was pulled back to expose the 4-ft-long screens once the desired depth was reached. Piezometers were installed to (total) depths ranging from 7 to $16 \mathrm{ft}$ beneath the surface; hand-driven piezometers could be installed to a total depth of about $8 \mathrm{ft}$.

Because only four steel screens for piezometers were available, several PVC piezometers were installed at the phase 3 sites. The steel drive casings were driven to the desired depth and pulled back to expose the soil. The PVC casingand-screen piezometers were then installed inside the steel casings such that the PVC screen was within the open interval. The steel casings remained to seal the surface of the hole and soils in the unscreened intervals.

After sampling, the piezometers were removed and the open holes were filled with bentonite chips to about 3 to 6 in. below grade. The last few inches of the boreholes were filled with topsoil and tamped down.

\section{Water-Quality Sampling Methods and Analysis}

All water samples were collected by use of a peristaltic pump with either polyethylene or Teflon tubing. Tubing was cleaned with nonphosphate detergent and deionized water, followed by sterilization in an autoclave before each use. Water from phase 2 piezometers was analyzed for nutrients, chloride, and E. coli bacteria concentrations. Water from phase 3 piezometers was analyzed for nutrient, chloride, nitrogen isotope, wastewater compound, and $E$. coli bacteria concentrations.

Duplicate samples and blanks were collected for quality-control purposes. These samples were collected to identify any bias or variability associated with sample collection or laboratory methods. Two duplicate samples were collected for chloride and nutrients. Results of the duplicate samples were compared qualitatively with the results of the field samples. The two sample sets were comparable (less than 10 percent difference) except for one ammonia sample, which had a 65percent difference between the two samples. Blank samples for chloride, nutrients, and wastewater compounds were collected by pumping blank water from the supply bottle to the sample bottle. One blank sample was collected for nutrients and one for chloride; no analytes were detected in the blank samples for nutrients and chloride. The blank sample for wastewater compounds is discussed later. Piezometer blanks were tested for E. coli to confirm cleaning and disinfection between sites. These blanks were collected prior to installation by rinsing the casing and screens with sterile deionized water. Five piezometer-screen blanks were tested at four different sites for $E$. coli; none of the five blanks yielded any $E$. coli bacteria.

\section{Nutrients and Chloride}

Nutrient and chloride analyses were done by the USGS National Water Quality Laboratory (NWQL) in Denver, Colo. The nutrient samples were analyzed for ammonia, nitrite, nitrite plus nitrate, and orthophosphate concentrations (Fishman, 1993); the reporting limits, respectively, were 0.04, $0.008,0.06$, and $0.018 \mathrm{mg} / \mathrm{L}$. Nitrate concentrations were determined by subtracting nitrite concentrations from the nitrite plus nitrate concentration. Chloride analysis was done by ion-exchange chromatography (Fishman and Friedman, 1989) and had a reporting limit of $0.2 \mathrm{mg} / \mathrm{L}$.

\section{Nitrogen and Oxygen Isotopes and Wastewater Compounds}

Analyses of nitrogen and oxygen isotopes were done by the USGS Reston Stable Isotope Lab (RSIL) in Reston, Va. Nutrient samples were collected at the same time as the isotope samples to determine the concentration of nitrate. Analyses of wastewater compounds were done by the USGS NWQL. Chemicals that were analyzed for and their laboratory reporting limits are listed in table 1 . Some analytes were reported as estimated concentrations, which means that compound was present but the concentration was too low to quantify accurately. The results of the duplicate wastewater sample are shown in table 10. The wastewater blank sample contained two estimated concentrations, for acetophenone and DEET (N,N-diethyl-meta-toluamide), and both estimated 
concentrations were $0.1 \mu \mathrm{g} / \mathrm{L}$. The laboratory methods used are described in Zaugg and others (2002).

\section{E. coli Sampling and Analysis Methods}

All equipment used in water-sample collection, such as pump tubing and bottles, was sterilized by autoclave. Water samples from piezometers and HSTS were analyzed (plated) for E. coil in the field or at the USGS Ohio Water Microbiology Laboratory (OWML) in Columbus, Ohio. Additionally, scat samples were collected at some sites for non-HSTS $E$. coli sources, such as outdoor pets and wildlife. When samples arrived at the OWML, they were logged into a project-specific tracking system. Cultivation was always attempted within 24 hours of sample collection; however, in some cases, multiple cultivation attempts were needed to obtain $E$. coli isolates. Standard operating procedures, quality assurance, and quality control were followed (Francy and others, 2004).

The membrane filtration method using mTEC agar (U.S. Environmental Protection Agency, 2000) was used to cultivate and enumerate $E$. coli colonies from piezometer water samples. In cases where water samples were too turbid to analyze by membrane filtration, Colilert (Idexx Laboratories, Inc, Westbrook, Maine) was used to enumerate $E$. coli in a most-probable-numbers (MPN) format.

Nonstandard sampling and cultivation was required to obtain E. coli from known-source samples. Septic systems were sampled by dipping sterile cotton swabs into the settling tanks or diverter box, which allowed the transfer of partially treated wastewater into buffer vials. Feces samples from non-HSTS sources were sampled by transferring small parts of the interior from each fecal mass to buffer vials. Then inoculated buffer vials were vortexed vigorously to disperse solids. Dilutions were prepared at a ratio of 1:10 from each feces suspension. Sterile 10- $\mu \mathrm{L}$ loops were used to streak the dilutions onto mTEC agar for selective cultivation of $E$. coli. If no growth was observed after a 24-hour incubation, then cultivation from the undiluted slurry was attempted by streaking $10 \mu \mathrm{L}$ and plating $1 \mathrm{~mL}$ (by membrane filtration) onto mTEC agar. If distinct typical colonies were not obtained on this attempt, then a third attempt was made by filtration or streaking of samples as indicated by prior results. If distinct typical colonies were not obtained in the third attempt, then the sample was considered unusable.

Table 1. Wastewater-method compound names, USGS National Water Quality Laboratory reporting limits, and possible compound uses (modified from Zaugg and others, 2002).

[Units are micrograms per liter; F, fungicide; H, herbicide; I, insecticide; GUP, general use pesticide; FR, flame retardant; WW, wastewater; Manuf, manufacturing; \%, percent; >, greater than; CP, combustion product; UV, ultraviolet; --, no data]

\begin{tabular}{|c|c|c|}
\hline Compound name & $\begin{array}{c}\text { Laboratory } \\
\text { reporting } \\
\text { limit }\end{array}$ & Possible compound uses or sources \\
\hline 1,4-Dichlorobenzene & 0.5 & Moth repellant, fumigant, deodorant \\
\hline 1-Methylnaphthalene & 0.5 & $2-5 \%$ of gasoline, diesel fuel, or crude oil \\
\hline 2,6-Dimethylnaphthalene & 0.5 & Present in diesel/kerosene (trace in gasoline) \\
\hline 2-Methylnaphthalene & 0.5 & $2-5 \%$ of gasoline, diesel fuel, or crude oil \\
\hline 3-Methyl-1H-indole (skatol) & 1 & Fragrance, stench in feces and coal tar \\
\hline 3-tert-Butyl-4-hydroxyanisole (BHA) & 5 & Antioxidant, general preservative \\
\hline 4-Cumylphenol & 1 & Nonionic detergent metabolite \\
\hline 4-n-Octylphenol & 1 & Nonionic detergent metabolite \\
\hline 4-tert-Octylphenol & 1 & Nonionic detergent metabolite \\
\hline Anthraquinone & 0.5 & Manuf dye/textiles, seed treatment, bird repellant \\
\hline Benzo $[a]$ pyrene & 0.5 & Regulated PAH, used in cancer research, CP \\
\hline Benzophenone & 0.5 & Fixative for perfumes and soaps \\
\hline beta-Sitosterol & 2 & Plant sterol \\
\hline beta-Stigmastanol & 2 & Plant sterol \\
\hline Bisphenol A & 1 & Manuf polycarbonate resins, antioxidant, FR \\
\hline Bromacil & 0.5 & H (GUP), $>80 \%$ noncrop usage on grass/brush \\
\hline Bromoform & 0.5 & WW ozination byproduct, military/explosives \\
\hline Caffeine & 0.5 & Beverages, diuretic, very mobile/biodegradable \\
\hline
\end{tabular}


Table 1. Wastewater method compound names, USGS National Water Quality Laboratory reporting limits, and possible compound uses.-Continued

[Units are micrograms per liter; F, fungicide; H, herbicide; I, insecticide; GUP, general use pesticide; FR, flame retardant; WW, wastewater; Manuf, manufacturing; \%, percent; >, greater than; CP, combustion product; UV, ultraviolet; --, no data]

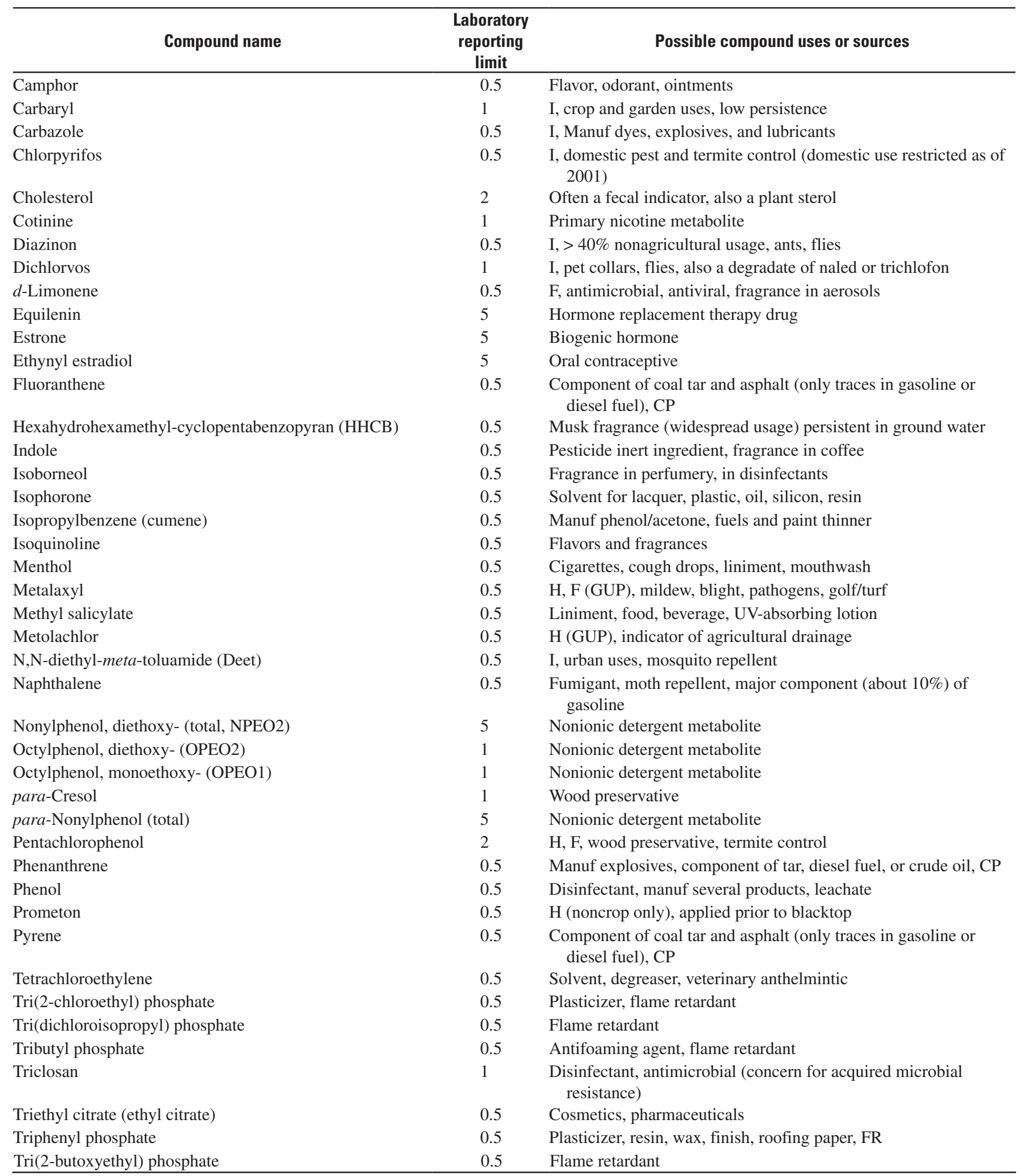


E. coli isolates were characterized by rep-PCR genomic analysis by a protocol similar to that reported by Rademaker and deBruijn (1997), modified and standardized by Bacterial Barcodes (2004). Greater detail of the following steps is provided in Appendix 1. Genetic information in the form of the deoxyribonucleic acid (DNA) chromosome was extracted physically from each $E$. coli culture. Target regions of the chromosome were amplified (reproduced) by the polymerase chain reaction (PCR). The PCR products were separated and visualized, with the result being a banding pattern for each isolate. An example of banding patterns is given in figure 6. The banding patterns are a way of distinguishing $E$. coli isolates that are genetically different.

$E$. coli reproduce when one mother cell splits in two to create genetically identical daughter cells (clones). Over time, this type of reproduction results in "clonal lineages" of daughter cells. The specific temperature, gut shape, food sources, exposure to antibiotics, and possibly other factors in an individual gut result in better survival of some clonal lineages over others. The end result in individual humans is that the $E$. coli in feces at any given time are dominated by one or a few clonal lineages (Whittam, 1989). Furthermore, different clonal lineages are dominant at differen times in individuals (Caugant and others, 1981). Over any short time frame (days to weeks), therefore, a HSTS receiving waste from a single family is expected to be dominated by a few types of $E$. coli, and those types of $E$. coli are expected to be different from the types carried by neighboring families, outdoor pets, and local wildlife.

The PCR patterns described above are one way to tell one clonal lineage (type) of $E$. coli from another. When the same type of E. coli are found in a HSTS and nearby piezometer water or curtain drain effluent, the most likely source of the $E$. coli in the piezometer water or curtain drain effluent is the HSTS. Non-HSTS feces samples and ground-water samples were collected in this study to guard against the possibility that the HSTS and other feces sources both carried the same type of E. coli within the time frame of the study.

\section{Coliphage Sampling and Analysis Methods}

Bacteriophage are viruses that infect bacteria, and coliphage are bacteriophage that mostly infect $E$. coli. The intent of measuring for coliphage was twofold: coliphage are an alternate indicator of fecal contamination and may be better indicators of subsurface virus transport than $E$. coli, and it is possible to get an idea of whether coliphage are associated with human-origin feces by genetic typing (Cole and others, 2003). If a piezometer yielded enough water, 250 $\mathrm{mL}$ of water was collected into sterile polypropylene bottles and shipped on ice to the OWML for analysis. Analysis was initiated within 72 hours of samples collected in accordance with Francy and others (2004). Samples were analyzed by a protocol based on USEPA standard method 1602 (U.S. Environmental Protection Agency, 2001), the single agar layer method. Coliphage were infrequently detected in the samples tested; therefore, genetic typing of coliphage was not done as part of this study.

\section{Description of Sampling Locations}

Sampling piezometers were installed at 20 sites in 9 counties and 6 soil regions throughout Ohio (table 2, figs. 1 and 2). For phase 2, at least two piezometers were installed at each site adjacent to an active leach line. Despite an unusually wet year, 8.53 in. above normal statewide (Cashell and Kirk, 2003), water could not be obtained at eight sites. Of the other 12 sites, 5 had water in only 1 piezometer, and at several sites the available water volume was so limited that only some of the target constituents could be sampled for. The difficulty in obtaining water could be due to one or more factors, including the poor permeability of the clay soils, smearing of soil during piezometer installation, not intercepting a flow path, and (or) active evapotranspiration above the leach field. Two of twelve sites sampled in phase 2 were used in phase 3 sampling.

Table 2. Counties, soil regions, and numbers of sites investigated in Ohio.

\begin{tabular}{lccc}
\hline \multicolumn{1}{c}{ County } & $\begin{array}{c}\text { Soil region } \\
\text { (figure 1) }\end{array}$ & $\begin{array}{c}\text { Number of sites } \\
\text { investigated }\end{array}$ & $\begin{array}{c}\text { Number of sites } \\
\text { sampled }\end{array}$ \\
\hline Delaware & 5 & 1 & 1 \\
Fairfield & 5 & 1 & 0 \\
Franklin & 4 & 1 & 1 \\
Fulton & 1 & 2 & 2 \\
Greene & 4 & 5 & 4 \\
Hardin & 3 & 3 & 1 \\
Hocking & 10 & 1 & 0 \\
Licking & 5 & 2 & 1 \\
Knox & 8 & 4 & 2 \\
\hline
\end{tabular}

\section{Phase 2-Unsampled Sites}

The eight sites where no water could be obtained from any of the piezometers are listed in table 3 . These piezometers were dry despite a prior monthly rainfall that was greater than normal by 1.16 in (Danville) to 2.91 in (Kenton) (National Oceanographic and Atmospheric Administration (NOAA) 2003a, 2003b, 2003c, 2003d, 2003e, 2003f). The cumulative precipitation at NOAA stations near the sites for the 2 weeks prior to sampling is listed in table 2 . The soils at these sites are mapped as well drained to very poorly drained silt and clay loams with permeabilties ranging from moderate to slow. The piezometers were installed from 3 to $4 \mathrm{ft}$ from leach lines, with 4-ft screened intervals ranging from 4 to 16 ft deep. Sampling was attempted the day after installation. Appendix 2 gives more details for the sites. 


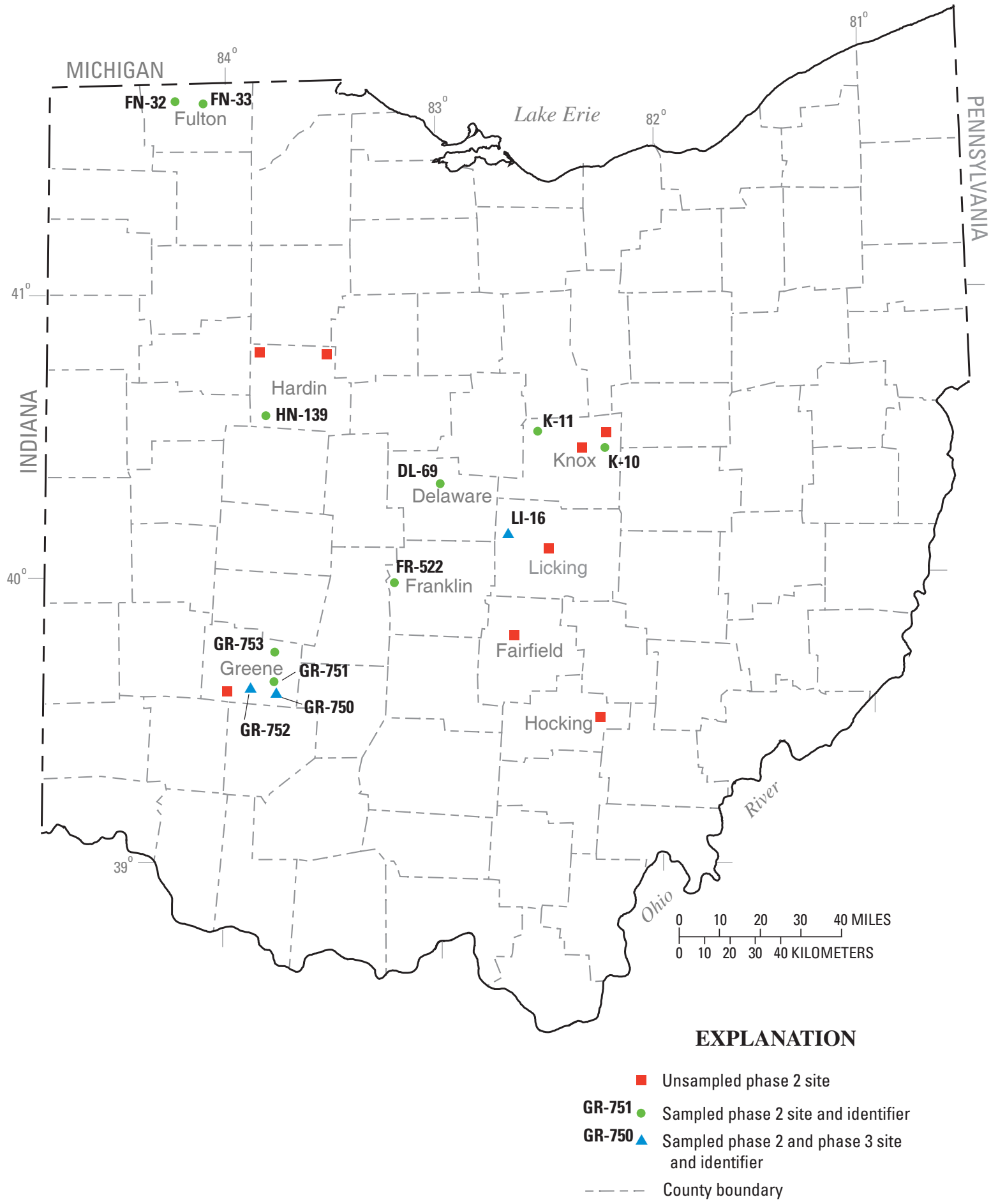

Figure 2. Location of phase 2 and phase 3 sites. 
Table 3. Location, rainfall, and screen-interval data for sites with piezometers that could not be sampled in Ohio.

[Rainfall is the cumulative amount for a two-week period prior to sampling at stations near sites (National Oceanic and Atmospheric Administration, 2003a, 2003b, 2003c, 2003d, 2003e, 2004); bls, below land surface]

\begin{tabular}{lccccc}
\hline $\begin{array}{c}\text { County } \\
\text { and } \\
\text { number } \\
\text { of sites }\end{array}$ & $\begin{array}{c}\text { Soil } \\
\text { region }\end{array}$ & $\begin{array}{c}\text { Rainfall } \\
\text { (inches) }\end{array}$ & $\begin{array}{c}\text { Sampling } \\
\text { date }\end{array}$ & $\begin{array}{c}\text { Shallow } \\
\text { screen } \\
\text { depth } \\
\text { (feet bls) }\end{array}$ & $\begin{array}{c}\text { Deep } \\
\text { screen } \\
\text { depth } \\
\text { (feet bls) }\end{array}$ \\
\hline Fairfield $^{\mathrm{a}}$, 1 & 5 & 1.0 & $10-16-03$ & $4-8$ & $9-13$ \\
& & 1.97 & $11-20-03$ & 10.5 & 10.5 \\
Greene, 1 & 4 & 1.65 & $07-31-03$ & $4-8$ & $12-16$ \\
Hardin, 2 & 3 & 2.51 & $08-07-03$ & $0-4^{\mathrm{b}}, 4-8$ & $12-16$ \\
& & 2.51 & $08-08-03$ & $4-8$ & $12-16$ \\
Hocking, 1 & 10 & $2.55^{\mathrm{e}}$ & $11-20-03$ & $(2) 4-8^{\mathrm{c}}$ & \\
Licking, 1 & 5 & $2.0^{\mathrm{f}}$ & $01-21-04$ & $3.5-7.5^{\mathrm{c}}$ & $4-8^{\mathrm{c}}$ \\
Knox, 2 & 8 & 1.42 & $08-27-03$ & $3-7$ & $4-8^{\mathrm{d}}$ \\
& & 1.41 & $08-28-03$ & $4-8$ & $12-16$ \\
\hline
\end{tabular}

a Two sets of piezometers were installed at one site. The second set of piezometers was installed at an angle such that screens were about $7.2 \mathrm{ft}$ directly beneath the leach line.

${ }^{\mathrm{b}}$ A second shallow piezometer was installed after no sample was obtained from the first piezometer.

${ }^{\mathrm{c}}$ Because of site conditions, piezometers were hand-driven and thus both were shallow.

${ }^{\mathrm{d}}$ Bedrock was encountered at about 8 feet.

${ }^{\text {e }}$ Precipitation at the Laurelville station.

${ }^{\mathrm{f}}$ Precipitation fell as snow.

\section{Phase 2-Sampled Sites}

At 12 sites, water was obtained from 1 or more of the piezometers installed (table 4). All the piezometers were installed from 3 to $4 \mathrm{ft}$ from an active leach line with 4 - $\mathrm{ft}$ screened intervals ranging from 4 to $16 \mathrm{ft}$ deep. The soils at most these sites are mapped as well-drained to very poorly drained silt and clay loams with permeabilties ranging from moderate to slow. The Fulton County sites are mapped as having sandy textures and rapid permeabilties. Sufficient water for complete analyses (chloride, nutrients, and microbiological) was obtained from both piezometers at only five of these sites (table 4); at three sites, sufficient water was obtained for only bacteria analyses. Appendix 3 gives more details for the sites.

\section{Phase 3 Sites}

Two Greene County sites, GR-750 and GR-752, were selected for phase 3 sampling (fig. 2). At a third site, LI-16, bacteria were collected from phase 2 piezometers and were saved for rep-PCR analysis; additional piezometers were not installed nor were wastewater samples collected.

Table 4. Locations, rainfall, screen intervals, and samples collected for Phase 2 sites in Ohio.

[Rainfall is the cumulative amount for a two-week period prior to sampling at stations near sampled sites (National Oceanic and Atmospheric Administration, 2003a, 2003b, 2003c, 2003d, 2004); bls, below land surface; microbiological samples include Escherichia coli (E.coli), coliphage and (or) total coliform; N, no sample collected; Y, sample collected]

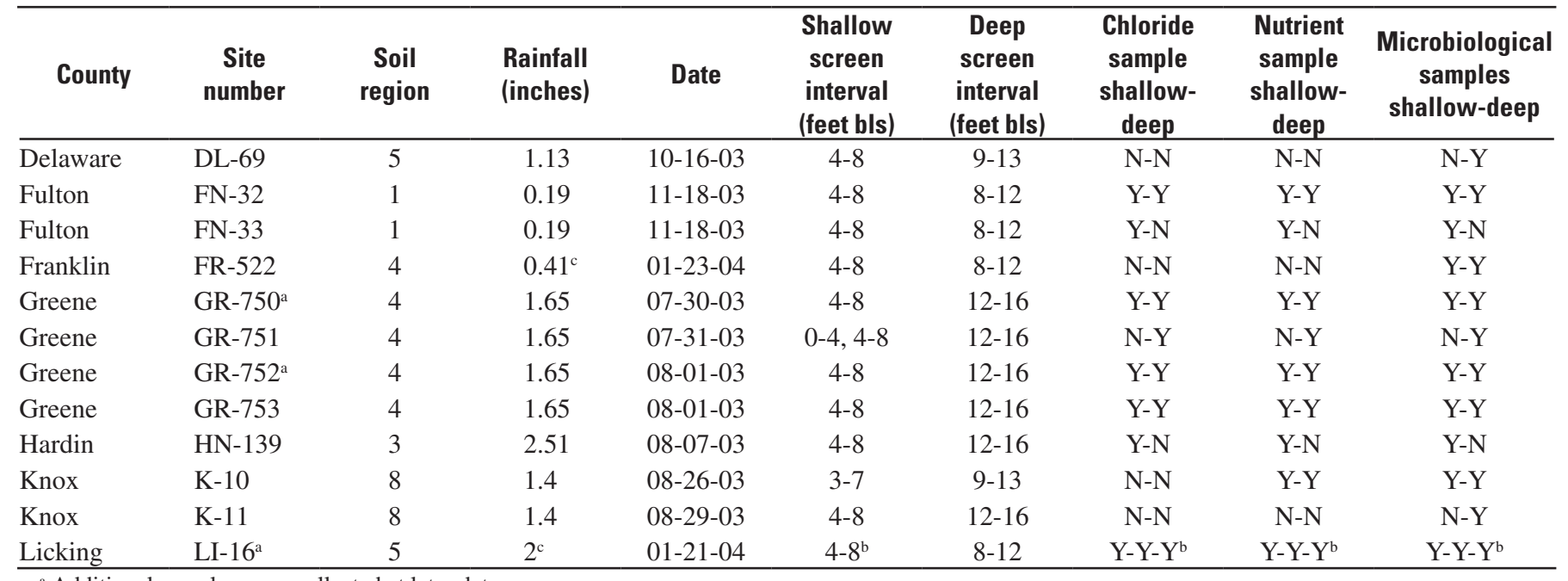

${ }^{a}$ Additional samples were collected at later dates.

b Two wells with screens from 4-8 feet below land surface were installed. Samples were collected from both shallow wells.

c Some of the precipitation fell as snow. 


\section{GR-750}

After confirmation of $E$. coli detection in phase 2 samples, 18 additional piezometers were installed to varying depths during 2 visits (fig. 3). During the first phase 3 visit, in mid-September, piezometers 3 through 8 were installed. The piezometers were installed about $4 \mathrm{ft}$ from an active leach line and screened from 4 to $8 \mathrm{ft}$ deep. Water was collected from these piezometers over the next several days. The water samples were analyzed for chloride, nutrients, wastewater compounds, and bacteria. In addition, the residential water well, the curtain drain (at the cleanout port), and three unknown fecal deposits (from the ground surface) were sampled for bacteria analysis. Bacteria colonies were saved for rep-PCR analysis.

During the second phase 3 visit, in mid-October, 12 additional piezometers (piezometers 9-20) were installed at various depths and distances from the end of the active leach line, both inside and outside the curtain drain (fig. 3). These locations were selected on the basis of bacteria counts from piezometers 1-8 and to investigate bacterial movement past the curtain drain. Piezometers 9-20 were sampled only for $E$. coli bacteria. Samples for bacteria and rep-PCR analysis also were collected from dog feces and unknown fecal samples on the site. Bacteria colonies were saved for rep-PCR.

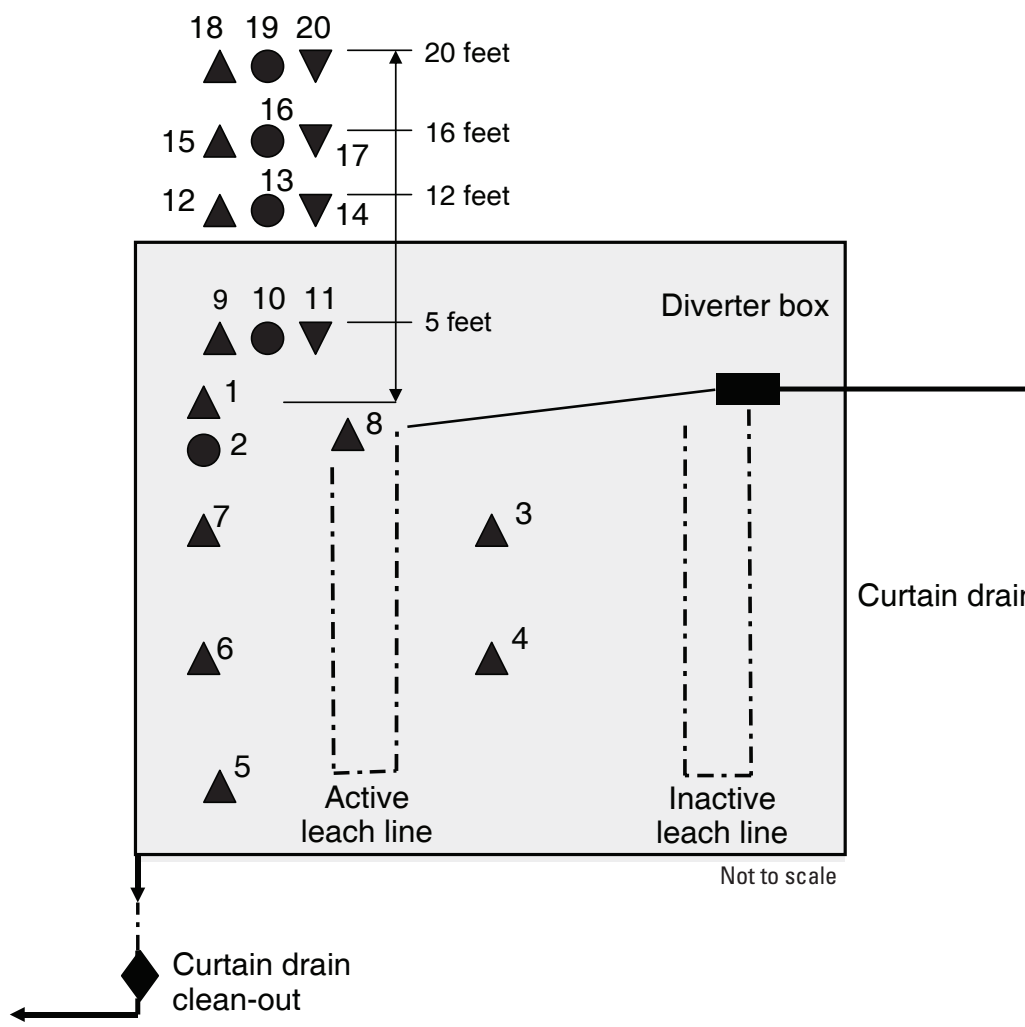

\section{EXPLANATION}

Piezometers, screened depths (feet below ground), and identification number

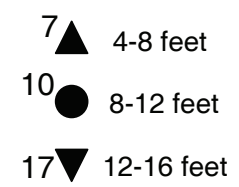

Figure 3. Schematic of septic system and piezometers at site GR-750 in Greene County, Ohio. 


\section{GR-752}

After confirmation of $E$. coli detection in the phase 2 samples, six additional piezometers (piezometers 3-8) were installed at various distances from the active leach line (fig. 4). These piezometers were all screened from 4 to $8 \mathrm{ft}$. Two piezometers, 6 and 8, were installed outside of the curtain drain. The curtain drain discharged to an open ditch about 500 $\mathrm{ft}$ from the property. The curtain-drain discharge could not be sampled for bacteria analysis because the drain discharge was level with water in the ditch. Samples for bacteria and rep-PCR analysis also were collected from dog feces on the site. Water was collected from these piezometers over the next several days. The water samples were analyzed for chloride, nutrients, wastewater compounds, and bacteria. Bacteria colonies were saved for rep-PCR.
$\mathrm{LI}-16$

At LI-16, three piezometers were installed during phase 2 (fig. 5); although no additional piezometers were installed at this site, the bacteria detected in the phase 2 samples were saved and analyzed by rep-PCR. There was no apparent access point to the curtain drain(s), and the discharge point(s) could not be located.

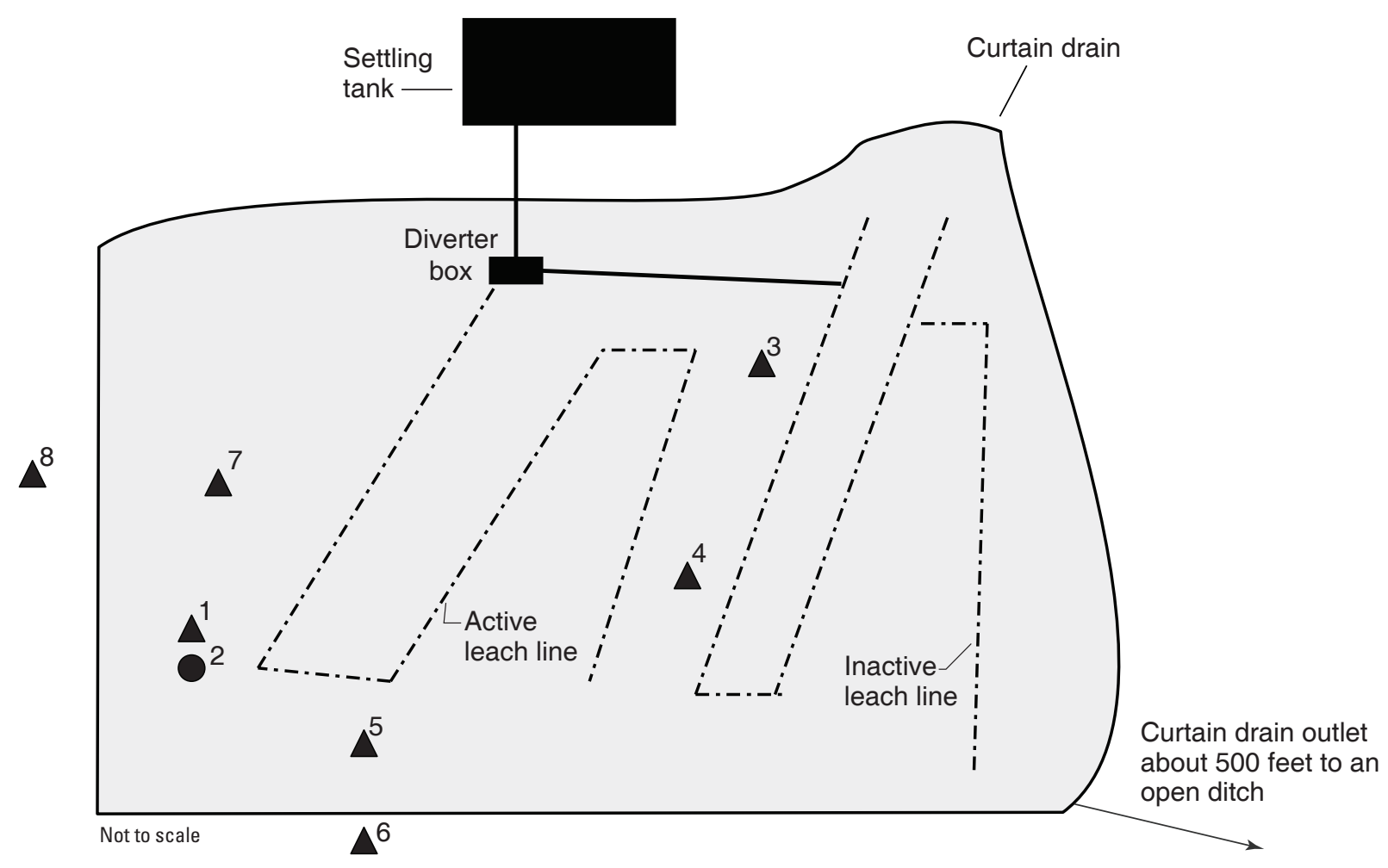

\section{EXPLANATION}

Piezometers, screened in intervals

(feet below ground),

and identification numbers

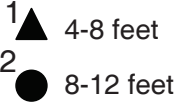

Figure 4. Schematic of septic system and piezometers at site GR-752 in Greene County, Ohio. 


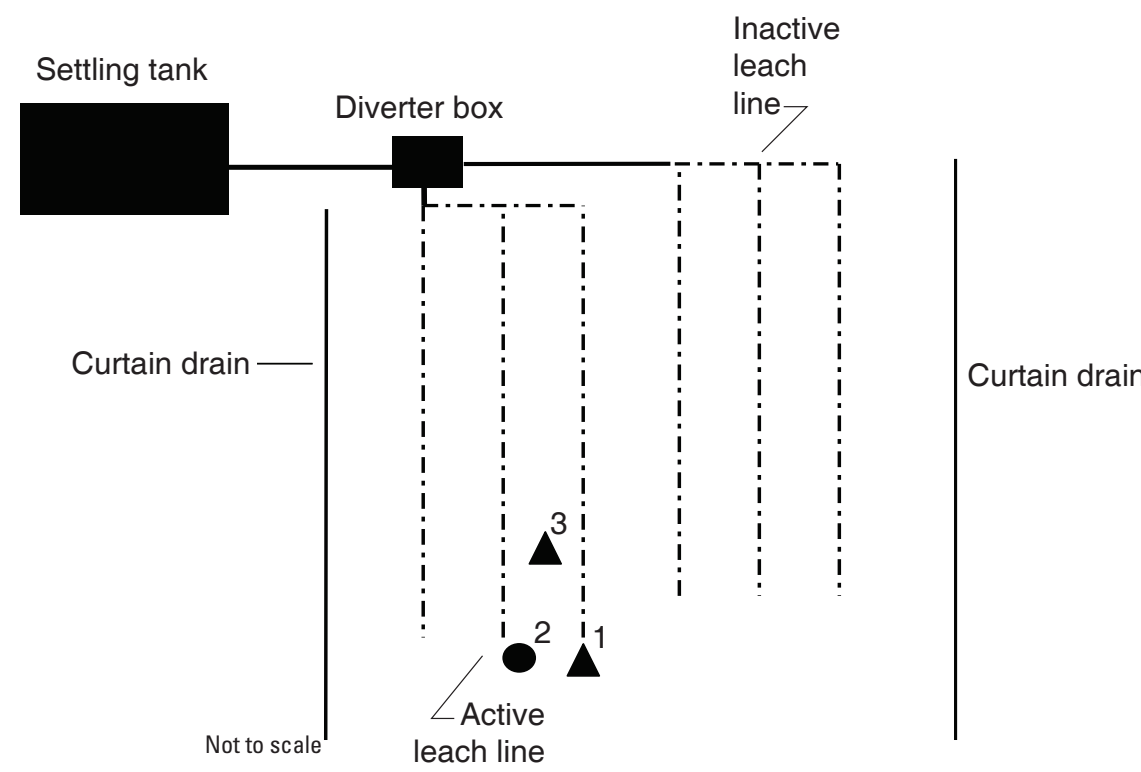

\section{EXPLANATION}

Piezometers, screened depths (feet below ground), and identification number

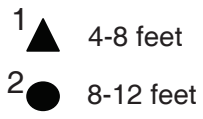

Figure 5. Schematic of septic system and piezometers at site LI-16 in Licking County, Ohio.

\section{Occurrences and Sources of Wastewater-Related Compounds}

\section{Nutrients}

Nutrients are ions or organic compounds that contain nitrogen or phosphorus. Nitrogen concentrations are of concern with respect to human-health issues; for drinking water the MCL (Maximum Contaminant Level) established for nitrite is $1 \mathrm{mg} / \mathrm{L}$ (as N), and that for nitrate is $10 \mathrm{mg} / \mathrm{L}$ (as N) (U.S. Environmental Protection Agency, 2004). Nitrogen fertilizers and sewage are common sources of nitrogen contamination in waters.

Samples for nutrient analyses were collected from 27 piezometers at 9 sites (tables 4 and 5). The nutrients analyzed for in this study were ammonia, orthophosphate, nitrite, and nitrate. Ammonia was detected in water from 21 piezometers and ranged from an estimated 0.02 to $5.68 \mathrm{mg} / \mathrm{L}$. Orthophos- phate was not detected in any of the samples. Nitrite and nitrate were detected in water from nine piezometers. Nitrite concentrations were below the MCL, with concentrations ranging from an estimated 0.004 to $0.386 \mathrm{mg} / \mathrm{L}$ as $\mathrm{N}$.

Baker and others (1989) analyzed more than 16,000 ground-water samples from wells in Ohio for nitrate; of these samples, 2.9 percent had nitrate concentrations in excess of 10 $\mathrm{mg} / \mathrm{L}$, and 68.2 percent had concentrations less than $0.3 \mathrm{mg} /$ $\mathrm{L}$; the average concentration was $1.32 \mathrm{mg} / \mathrm{L}$. Baker and others (1989) defined $0.3 \mathrm{mg} / \mathrm{L}$ or less as the concentration representing background nitrate levels in Ohio. Nitrate concentrations between 3.1 to $10 \mathrm{mg} / \mathrm{L}$ may indicate effects of human activity. Nitrate concentrations in excess of $10 \mathrm{mg} / \mathrm{L}$ are most likely due to human activity. Water from two piezometers at two sites in Greene County, GR-752 and GR-753 had nitrate concentrations between $3.1 \mathrm{mg} / \mathrm{L}$ and $10 \mathrm{mg} / \mathrm{L}$; however, concentrations in samples from other piezometers at both sites were below 3.1, including some analyses below the detection limit. At three piezometers at two sites in Fulton County, FN-32 and FN-33, nitrate concentrations exceeded $10 \mathrm{mg} / \mathrm{L}$. 
Table 5. Specific conductance and chloride and nutrient concentrations in ground-water samples from phase 2 and phase 3 piezometers at various sites in Ohio.

[bls, below land surface; $\mu \mathrm{s} / \mathrm{cm}$, microsiemens per centimeter; $\mathrm{mg} / \mathrm{L}$, milligrams per liter; <, less than; --, no sample; E, estimated value]

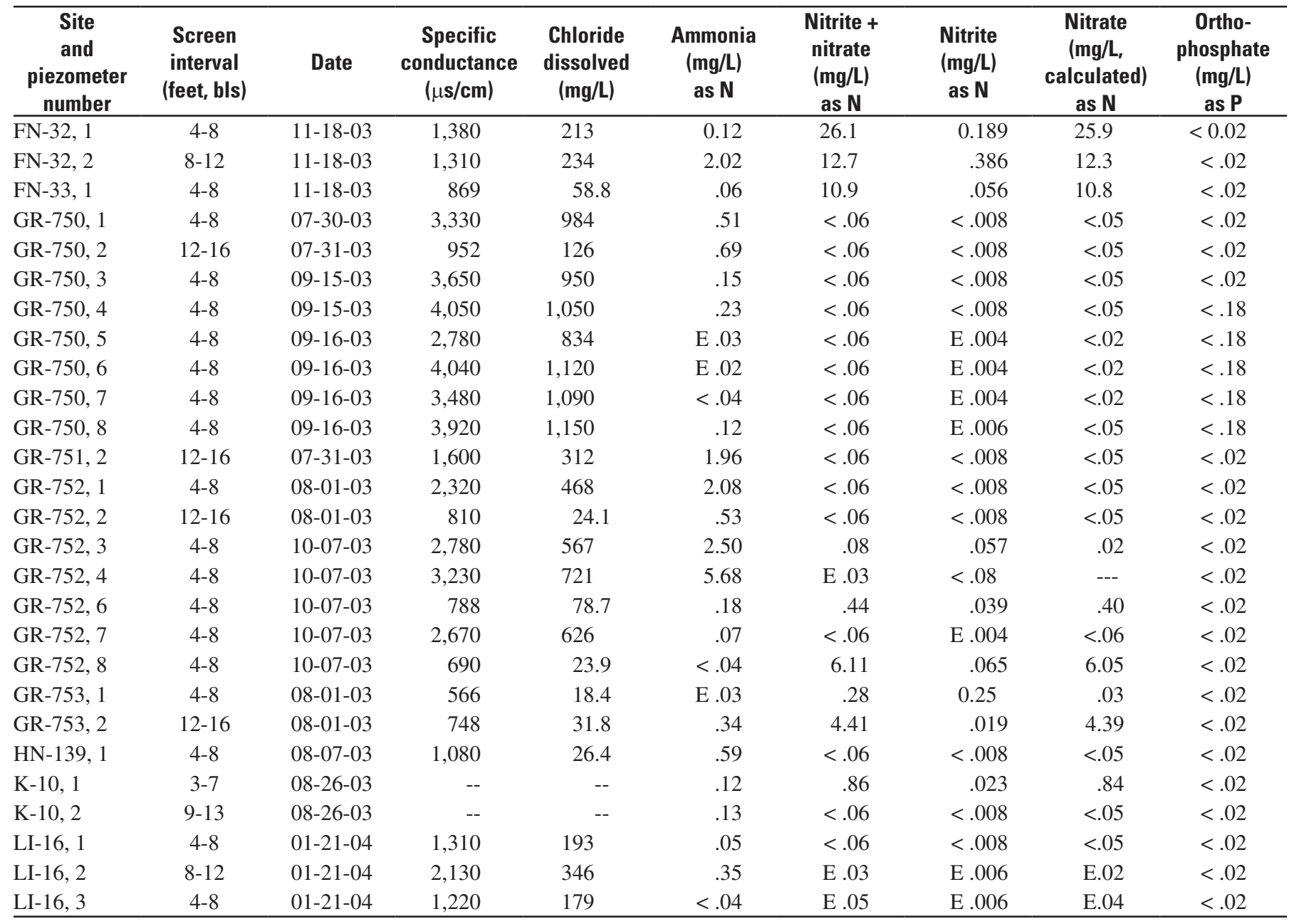

\section{Chloride}

Chloride is a conservative ion; that is, chloride in ground water is not involved in many chemical reactions. Chloride is sometimes used as a tracer in ground-water studies. Chloride is present in all natural waters, but concentrations are generally low; concentrations in precipitation inland from an ocean are generally less than $1 \mathrm{mg} / \mathrm{L}$ (Hem, 1989). The expectation in this study was that water from a HSTS source would have higher chloride concentrations than natural waters because septic effluent would likely retain residual chemicals from water softeners and (or) household products containing chloride.

Water samples for chloride analysis were collected from 25 piezometers at 8 sites (tables 4 and 5). Chloride concentrations ranged from 18.4 to $1,150 \mathrm{mg} / \mathrm{L}$, with a median concentration of $312 \mathrm{mg} / \mathrm{L}$. The highest concentrations were found in samples from seven of the shallow piezometers at GR-750; concentrations ranged from 834 to $1,150 \mathrm{mg} / \mathrm{L}$ with a median concentration of $1,050 \mathrm{mg} / \mathrm{L}$. At GR-752, samples from four of the seven shallow piezometers also had relatively high chloride concentrations, with a range from 468 to $721 \mathrm{mg} / \mathrm{L}$. Samples from the other two shallow piezometers had relatively low chloride concentrations, 78.7 and $24.1 \mathrm{mg} / \mathrm{L}$; these two piezometers were outside the curtain drain.

The degree to which septic effluent affected the chloride concentrations in this study cannot be directly determined, but the literature does provide some data for comparisons. Panno and others (2002) reported chloride concentrations from 91 to $5,620 \mathrm{mg} / \mathrm{L}$ for septic effluent with a median concentration of $186 \mathrm{mg} / \mathrm{L}$. In another study, chloride concentrations of 34.9 and $41.2 \mathrm{mg} / \mathrm{L}$ were found in samples from two household septic systems; both of these homes were on city-supplied water, and neither had water-softener systems (Dumouchelle, 
2004, unpublished data on file in the Columbus, Ohio, USGS office). Background chloride concentrations can be estimated from other studies. Chloride concentrations in samples from 21 wells screened in a sand and gravel glacial aquifer at Wright-Patterson Air Force Base (Dayton, Ohio, area) ranged from 2.0 to $98.8 \mathrm{mg} / \mathrm{L}$. Samples from another 17 wells at the base, also screened in the glacial aquifer, had multiple analyses from a 19 -year period; at every well the median concentrations were $80 \mathrm{mg} / \mathrm{L}$ or less (Dumouchelle and others, 1993). In Geauga County, in northeastern Ohio, samples from eight wells screened in glacial aquifers had chloride concentrations ranging from 1.0 to $74 \mathrm{mg} / \mathrm{L}$, with a median of 13.2 $\mathrm{mg} / \mathrm{L}$ (Jagucki and Darner, 2001).

It is important to note the piezometers in this study were not screened in aquifers but in clay-rich glacial sediments. In southeast Michigan, samples from 15 wells in glacial lakebed sediments had chloride concentrations from 11 to $530 \mathrm{mg} / \mathrm{L}$, with a median of $79 \mathrm{mg} / \mathrm{L}$ (Gillespie and Dumouchelle, 1989). Another study installed eight monitoring wells around Ohio in clay-rich glacial sediments and monitored chloride concentrations for 5 to 9 years. The number of analyses per well ranged from 85 to 408 . The maximum chloride concentrations ranged from 27 to $544 \mathrm{mg} / \mathrm{L}$; only one well had a maximum concentration greater than $150 \mathrm{mg} / \mathrm{L}$. Median chloride concentrations ranged from 4 to $41 \mathrm{mg} / \mathrm{L}$ (A.E. Kunze, U.S. Geological Survey, written commun. 2004).

Given the ranges of chloride concentrations discussed above, a conservative estimate is that samples in this study with chloride concentrations greater than $200 \mathrm{mg} / \mathrm{L}$ are most likely affected by HSTS effluent.

\section{Bacteria and rep-PCR Analysis}

Of the 12 phase 2 sites, E. coli bacteria were found in water from piezometers at 3 sites, GR-750, GR-752, and LI-16 (table 6). Phase 3 work was done only at GR-750 and GR-752 because LI-16 was sampled too late for inclusion. However, isolates from LI-16 were saved, and a sample from the septic tank was collected for use in rep-PCR analysis on phase 2 isolates. E. coli bacteria were found in water from 6 of the 12 phase 3 piezometers sampled. At GR-750, E. coli concentrations ranged from $<1$ to an estimated 4,500 col/100 $\mathrm{ml}$. At GR-752, E. coli concentrations ranged from $<1$ to 870 $\mathrm{col} / 100 \mathrm{ml}$.

Presumptive E. coli (Colilert and (or), TEC positive) from the three sites were saved, and from those cultures 187 isolates were characterized by rep-PCR analysis. The repPCR process produces a graphical display of the genetic makeup of an isolate. The similarity of any two isolates can be determined by comparing the displays of the genetic makeup (see Appendix 1 for more detail). A representation of 14 rep-PCR analysis is shown on figure 6. Each bar represents the genetic makeup of one isolate. On figure 6, differences in isolates (bars) A and B cannot be distinguished within the precision of the method; the same is true for isolates $\mathrm{C}$ through
E. Therefore, isolates A and B are considered the same, as are isolates $\mathrm{C}$ through $\mathrm{E}$. Similar isolates are assigned to a sequentially numbered group called an OTU (operational taxanomic unit). In some cases, professional judgement is required to decide whether isolates belong to an OTU. For example, isolates A-B and C-E (fig. 6) appear to be different on the basis of the intensity of a single band and are thus considered genetically distinct and assigned to separate OTUs. It is more clear, however, that isolate $\mathrm{F}$ is different from isolates A-E.

On the basis of rep-PCR results, 53 OTUs were identified in this study. Many OTUs contained isolates from only a single sample source such as an HSTS or a surface fecal sample. Those OTUs with isolates from more than one sample source indicate a link between those sources. The 17 OTUs that share isolates from more than one source are listed in table 7. For example, OTU 31 contains isolates from the HSTS, the curtain drain around the HSTS, and two piezometers. This means that the bacteria found in the HSTS was also found in the curtain drain and the piezometers, and the ultimate source of those bacteria was probably the associated household. Although not all the OTUs were confirmed as E. coli, the interpretation is the same for fecal-origin bacteria that did not confirm as $E$. coli (see Appendix 1 for an explanation).

\section{GR-750}

Bacteria from 11 OTUs were found in more than one sample (table 7); 9 of these were confirmed as E. coli bacteria. In eight cases, the OTUs indicate a link between the HSTS and a piezometer and (or) the curtain drain. E. coli and non- $E$. coli bacteria found in samples from the septic tank or diverter box were similar to those found in samples from piezometers GR-750 3, 4, 7, 8, 9, and in the curtain drain.

\section{GR-752}

Bacteria from four OTUs were found in more than one sample (table 7); two of these were confirmed as E. coli bacteria. In three cases, the OTUs indicate a link between the HSTS and a piezometer. E. coli and non- E. coli bacteria found in samples from the septic tank or diverter box were similar to those found in samples from piezometers GR-752 3 and 7. In addition, E. coli from dog feces were found in a sample from piezometer GR-752 7.

\section{$\mathrm{LI}-16$}

Bacteria from two OTUs were found in more than one sample (table 7); one confirmed as E. coli. One case, OTU 46, indicates a link between the HSTS and a piezometer. NonE. coli bacteria found in samples from the septic tank and diverter box were similar to those found in the sample from piezometer LI-16 1. 
Table 6. Escherichia coli and coliphage anaylses of ground-water samples from phase 2 and phase 3 piezometers at various sites in Ohio.

[bls, below land surface; E. coli, Escherichia coli; mL, milliliters; MPN, most probable number; <, less than; > greater than;--, no data; E, estimated value]

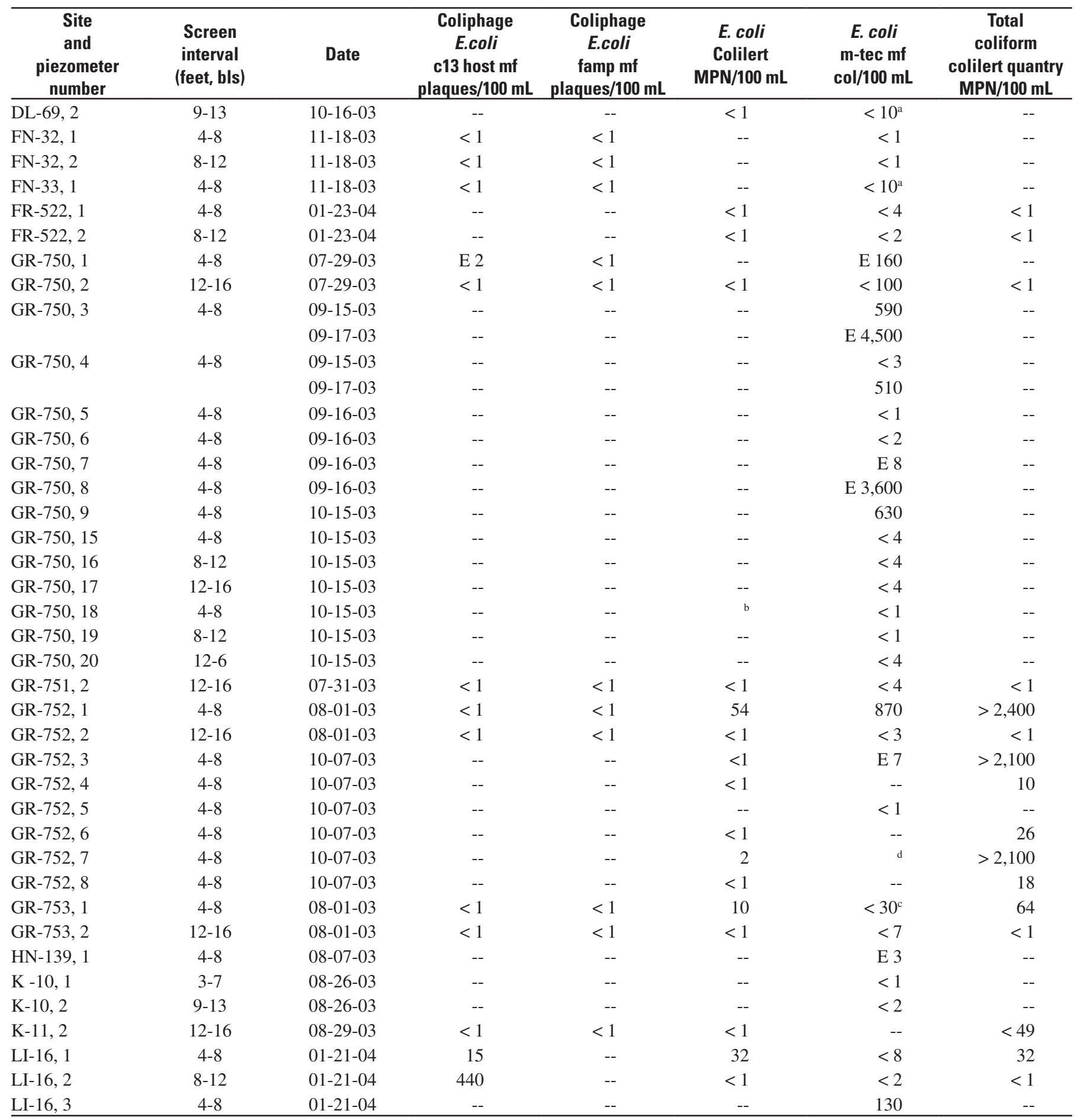

${ }^{a}$ Limited water was available, so only $30 \mathrm{~mL}$ could be used.

${ }^{\mathrm{b}}$ The sample concentration from the Colilert method was not recorded because of a lab error, but isolates were saved for rep-PCR analysis.

c The water sample was too turbid; nontarget growths were observed, but $E$. coli counts were 0 .

${ }^{\mathrm{d}}$ E. coli were present but not enumerated because of turbidity. 


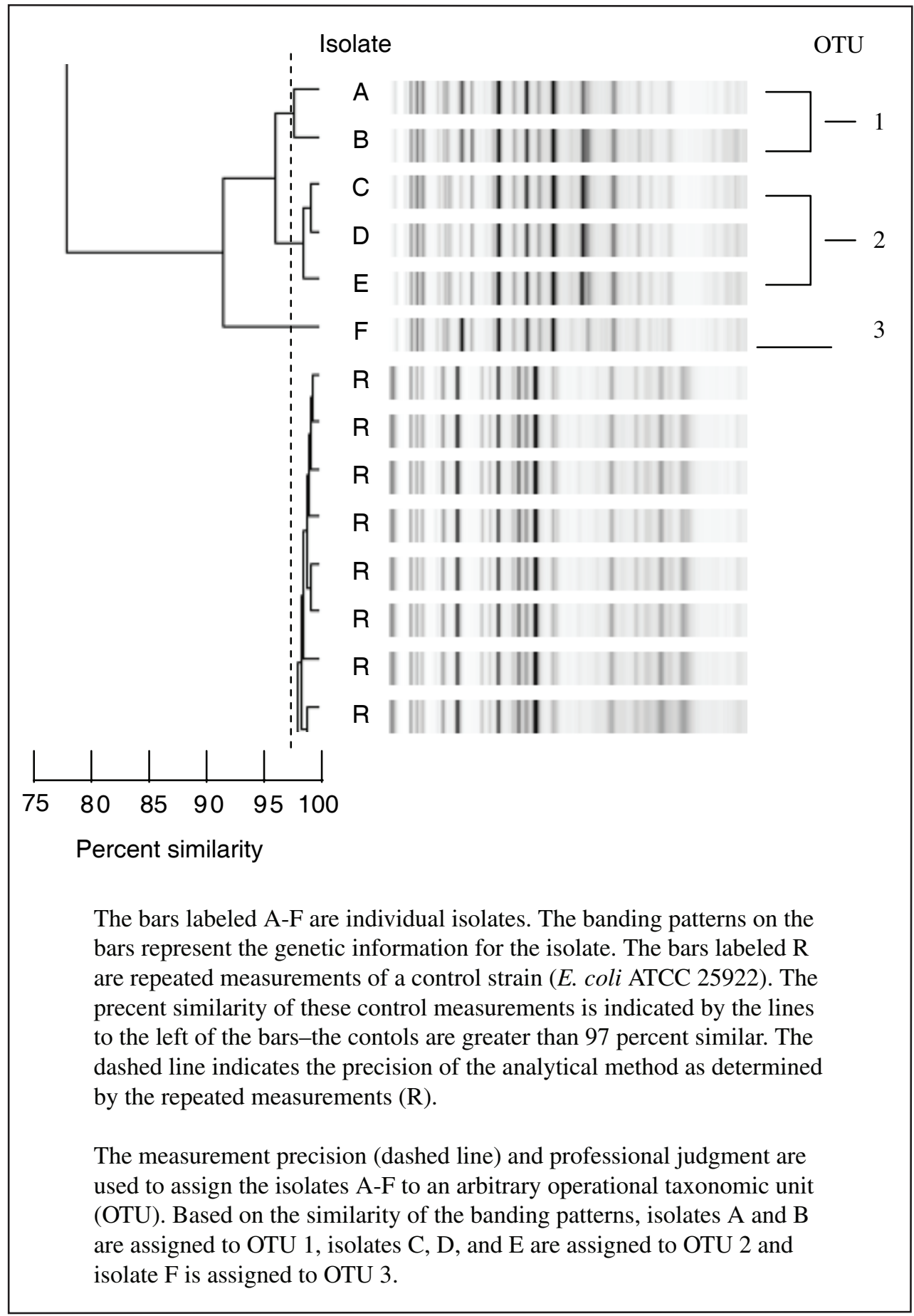

Figure 6. Example of results of rep-PCR analysis showing six isolates and multiple measurements of a single isolate, demonstrating the reproducibility of results. 
Table 7. Sites and characteristics of isolates in those Operational Taxonomic Units (OTU) found from more than one source.

[OTU, operational taxanomic unit; E.coli, Escherichia coli; HSTS, home sewage treatment system; Alt., alternate]

\begin{tabular}{|c|c|c|c|c|}
\hline OTU & Sample source & Date & $\begin{array}{c}\text { Number } \\
\text { of } \\
\text { isolates }\end{array}$ & $\begin{array}{c}\text { E. coli } \\
\text { confirmation } \\
\text { status } \\
\end{array}$ \\
\hline \multicolumn{5}{|c|}{ GR-750 } \\
\hline 1 & $\begin{array}{l}\text { GR-750 } 3 \\
\text { GR-750 } 8\end{array}$ & $\begin{array}{l}09-15-2003 \\
09-16-2003\end{array}$ & $\begin{array}{l}2 \\
1\end{array}$ & Confirmed \\
\hline 4 & $\begin{array}{l}\text { HSTS } \\
\text { Curtain drain } \\
\text { GR-750 } 7\end{array}$ & $\begin{array}{l}09-16-2003 \\
09-16-2003 \\
09-16-2003\end{array}$ & $\begin{array}{l}1 \\
1 \\
1\end{array}$ & Not E. coli \\
\hline 6 & $\begin{array}{l}\text { HSTS } \\
\text { GR-750 } 4\end{array}$ & $\begin{array}{l}10-15-2003 \\
09-16-2003\end{array}$ & $\begin{array}{l}1 \\
1\end{array}$ & Confirmed \\
\hline 11 & $\begin{array}{l}\text { HSTS } \\
\text { GR-750 } 3\end{array}$ & $\begin{array}{l}09-16-2003 \\
09-15-2003\end{array}$ & $\begin{array}{l}1 \\
1\end{array}$ & Confirmed \\
\hline 19 & $\begin{array}{l}\text { Alt. source-unknown } \\
\text { Curtain drain }\end{array}$ & $\begin{array}{l}09-16-2003 \\
10-15-2003\end{array}$ & $\begin{array}{l}1 \\
1\end{array}$ & Confirmed \\
\hline 20 & $\begin{array}{l}\text { HSTS } \\
\text { GR-750 } 3 \\
\text { GR-750 } 3 \\
\text { GR-750 } 4 \\
\text { GR-750 } 8\end{array}$ & $\begin{array}{l}09-16-2003 \\
09-15-2003 \\
09-16-2003 \\
09-16-2003 \\
09-16-2003\end{array}$ & $\begin{array}{l}7 \\
2 \\
4 \\
2 \\
1\end{array}$ & Confirmed \\
\hline 27 & $\begin{array}{l}\text { Alt. source-dog } \\
\text { GR-750 } 18\end{array}$ & $\begin{array}{l}09-16-2003 \\
10-15-2003\end{array}$ & $\begin{array}{l}1 \\
2\end{array}$ & Confirmed \\
\hline 31 & $\begin{array}{l}\text { HSTS } \\
\text { HSTS } \\
\text { GR-750 } 7 \\
\text { GR-750 } 9 \\
\text { Curtain drain }\end{array}$ & $\begin{array}{l}09-16-2003 \\
10-15-2003 \\
09-16-2003 \\
10-15-2003 \\
10-15-2003\end{array}$ & $\begin{array}{l}12 \\
3 \\
1 \\
9 \\
2\end{array}$ & Confirmed \\
\hline 32 & $\begin{array}{l}\text { HSTS } \\
\text { GR-750 } 9\end{array}$ & $\begin{array}{l}10-15-2003 \\
10-15-2003\end{array}$ & $\begin{array}{l}1 \\
1\end{array}$ & Confirmed \\
\hline 34 & $\begin{array}{l}\text { HSTS } \\
\text { GR-750 } 3 \\
\text { GR-750 } 8\end{array}$ & $\begin{array}{l}09-16-2003 \\
09-16-2003 \\
09-16-2003\end{array}$ & $\begin{array}{l}1 \\
1 \\
1\end{array}$ & Confirmed \\
\hline 39 & $\begin{array}{l}\text { HSTS } \\
\text { GR-750 } 7\end{array}$ & $\begin{array}{l}09-16-2003 \\
09-16-2003 \\
\end{array}$ & $\begin{array}{l}2 \\
2 \\
\end{array}$ & Not E. coli \\
\hline \multicolumn{5}{|c|}{ GR-752 } \\
\hline 23 & $\begin{array}{l}\text { HSTS } \\
\text { GR-752 } 7\end{array}$ & $\begin{array}{l}10-07-2003 \\
10-07-2003\end{array}$ & $\begin{array}{l}4 \\
1\end{array}$ & Confirmed \\
\hline 40 & $\begin{array}{l}\text { Alt. source-dog } \\
\text { GR-752 } 7\end{array}$ & $\begin{array}{l}10-07-2003 \\
10-07-2003\end{array}$ & $\begin{array}{l}2 \\
2\end{array}$ & Confirmed \\
\hline 51 & $\begin{array}{l}\text { HSTS } \\
\text { GR-752 } 8\end{array}$ & $\begin{array}{l}10-07-2003 \\
10-07-2003\end{array}$ & $\begin{array}{c}13 \\
1\end{array}$ & Not E. coli \\
\hline 52 & $\begin{array}{l}\text { HSTS } \\
\text { GR-752 } 3\end{array}$ & $\begin{array}{l}10-07-2003 \\
10-07-2003 \\
\end{array}$ & $\begin{array}{l}3 \\
1 \\
\end{array}$ & Not E. coli \\
\hline & & LI-16 & & \\
\hline 36 & $\begin{array}{l}\text { LI-16 } 1 \\
\text { LI-16 } 3\end{array}$ & $\begin{array}{l}01-21-2004 \\
01-21-2004\end{array}$ & $\begin{array}{l}3 \\
2\end{array}$ & Confirmed \\
\hline 46 & $\begin{array}{l}\text { HSTS } \\
\text { LI-16 } 3 \\
\end{array}$ & $\begin{array}{l}01-27-2004 \\
01-21-2004 \\
\end{array}$ & $\begin{array}{c}12 \\
2 \\
\end{array}$ & Not E. coli \\
\hline
\end{tabular}

\section{Nitrogen Isotopes and Wastewater Compounds}

Eleven phase 3 piezometers at GR-750 and GR-752 were sampled for nitrogen and oxygen isotopes (table 8). At the same time, water also was collected for nitrate analyses (table 5). Nitrate concentrations ranged from below the reporting limit to greater than $6 \mathrm{mg} / \mathrm{L}$ (GR-750 2-8, table 5). The requirement from the RSIL is that nitrate concentration of samples for isotopic analyses be at least $0.03 \mathrm{mg} / \mathrm{L}$ (G. Cottrell, U.S. Geological Survey, written commun., 2004). Because the nitrate concentrations were low in all the samples except GR-752 6 and 8 and the analyses are subject to error at low nitrate concentrations, interpretation of the data was not recommended by the RSIL. The sample from GR-752 6 had nitrite concentrations that were high relative to the nitrate concentrations, which also introduces problems for isotopic analysis. Thus, the only sample with interpretable isotope data was from GR-752 8; the ratio of $\delta^{15} \mathrm{~N}$ and $\delta^{18} \mathrm{O}$ indicate that the nitrogen in this sample possibly had an agricultural source and has undergone denitrification (J.K.Bohlke, U.S. Geological Survey, oral commun., 2004).

As previously stated, 11 phase 3 piezometers at GR-750 and GR-752 were sampled for wastewater compounds. Table 1 lists the wastewater analytes, the laboratory reporting limits, and possible sources of the compounds. Tables 9 and 10 list the compounds and concentrations found above the reporting limits in the samples. Most of the detected concentrations were at estimated concentrations, indicating that the concentrations were below the reporting limit. Among detected compounds are fecal indicators, fragrances, food and beverage additives, detergents, pesticides and repellants, flame retardants, and plasticizers.

The most significant aspect of results of the wastewater-compound analyses is the number of chemicals detected. At least two chemicals were detected in samples from every piezometer. More than 10 chemicals were detected in samples from 3 piezometers: GR-750 3 and 8 and GR-752 3. The most frequently detected chemical was DEET (N,N-diethylmeta-toluamide), and the second was phenol. At both sites, DEET was detected in all samples from piezometers, and some concentrations were above the reporting limit. Five other compounds also were found at least once in concentrations above their reporting limits (tables 9 and 10). This is in contrast to the results of other studies. In Shindel and others (2003), analyses of wastewater compounds in samples from 25 wells in southwestern Ohio are reported. Of these 25 samples, only 1 had more than 5 chemicals detected; in 9 samples, only 1 chemical was detected, and in 4 samples, nothing was detected. The most frequently detected chemical was phenol. Four wells had concentrations of phenol above the reporting limit; all other concentrations were reported as estimated values. The number of wastewater-related chemicals found in water from piezometers at GR-750 and GR-752 is evidence that wastewater moved laterally from the HSTS. 
Table 8. Nitrogen and oxygen isotope ratios in ground-water samples from phase 3 piezometers at sites GR-750 and GR-752, Greene County, Ohio.

[bls, below land surface; per mil, parts per thousand; nitrogen isotopes, relative to air; oxygen isotopes, relative to standard mean oceanic water]

\begin{tabular}{ccccc}
\hline $\begin{array}{c}\text { Site and } \\
\text { piezometer } \\
\text { number }\end{array}$ & $\begin{array}{c}\text { Screen } \\
\text { interval } \\
\text { (feet, bls) }\end{array}$ & Date & $\begin{array}{c}\delta^{\mathbf{1 5}} \mathbf{N} \\
\text { (per mil) }\end{array}$ & $\begin{array}{c}\delta^{18} \mathbf{0} \\
\text { (per mil) }\end{array}$ \\
\hline GR-750, 3 & $4-8$ & $09-15-03$ & +8.68 & +18.43 \\
GR-750, 4 & $4-8$ & $09-15-03$ & +7.25 & +23.62 \\
GR-750, 5 & $4-8$ & $09-16-03$ & +5.74 & +22.82 \\
GR-750, 6 & $4-8$ & $09-16-03$ & +7.36 & +34.12 \\
GR-750, 7 & $4-8$ & $09-16-03$ & +3.03 & +25.97 \\
GR-750, 8 & $4-8$ & $09-16-03$ & +6.97 & +34.49 \\
GR-752, 3 & $4-8$ & $10-07-03$ & +53.98 & +6.54 \\
GR-752, 4 & $4-8$ & $10-07-03$ & +10.90 & +29.82 \\
GR-752, 6 & $4-8$ & $10-07-03$ & +63.61 & +18.90 \\
GR-752, 7 & $4-8$ & $10-07-03$ & +14.23 & +20.40 \\
GR-752, 8 & $4-8$ & $10-07-03$ & +16.76 & +12.83 \\
\hline
\end{tabular}

Table 9. Wastewater-compound concentrations in groundwater samples from phase 3 piezometers at GR-750, Greene County, Ohio.

[All units are micrograms per liter; E, estimated, M, presence verified but not quantified; -- not detected]

\begin{tabular}{|c|c|c|c|c|c|c|}
\hline \multirow{2}{*}{ Compound } & \multicolumn{6}{|c|}{ GR-750 } \\
\hline & 3 & 4 & 5 & 6 & 7 & 8 \\
\hline 3beta-Coprostanol & -- & -- & -- & -- & -- & $\mathrm{M}$ \\
\hline $\begin{array}{l}\text { 3-Methyl-1H-indole } \\
\text { (skatol) }\end{array}$ & M & M & -- & -- & -- & 3 \\
\hline Acetophenone & -- & -- & -- & -- & -- & E.2 \\
\hline $\mathrm{AHTN}^{1}$ & E.1 & -- & -- & -- & -- & .6 \\
\hline Benzophenone & E.1 & E.1 & E.1 & -- & -- & E.1 \\
\hline Caffeine & E.1 & $\mathrm{M}$ & -- & -- & -- & E.2 \\
\hline Cholesterol & $\mathrm{M}$ & -- & -- & -- & -- & E 1 \\
\hline $\mathrm{HHCB}^{2}$ & E.1 & -- & -- & -- & -- & E.1 \\
\hline Isophorone & E.1 & $\mathrm{M}$ & M & -- & -- & E.1 \\
\hline Menthol & E. 3 & E.1 & -- & -- & -- & 1.0 \\
\hline Methyl salicylate & -- & -- & -- & -- & $\mathrm{M}$ & -- \\
\hline $\operatorname{Deet}^{3}$ & 4.5 & 3.3 & E. 3 & E.2 & E.2 & 3.6 \\
\hline $\mathrm{OPEO}^{4}$ & -- & -- & -- & -- & -- & $\mathrm{M}$ \\
\hline para-Cresol & 14 & 4 & -- & -- & -- & 45 \\
\hline Phenol & 1.7 & 1.4 & 1.9 & 1.5 & E.4 & 1.4 \\
\hline $\begin{array}{l}\text { Tri(dichloroisopropyl) } \\
\text { phosphate }\end{array}$ & -- & -- & -- & -- & -- & E .3 \\
\hline Triphenyl phosphate & -- & -- & -- & -- & -- & M \\
\hline \multicolumn{7}{|c|}{${ }^{1}$ Acetyl-hexamethyl-tetrahydro-naphthalene } \\
\hline \multicolumn{7}{|c|}{${ }^{2}$ Hexahydrohexamethyl-cyclopentabezopyran } \\
\hline \multicolumn{7}{|c|}{${ }^{3} \mathrm{~N}, \mathrm{~N}$-diethyl-meta-toluamide } \\
\hline${ }^{4}$ Octylphenol, monoeth & & & & & & \\
\hline
\end{tabular}

Table 10. Wastewater-compound concentrations in groundwater samples from phase 3 piezometers at GR-752, Greene County, Ohio.

[All units are micrograms per liter; E, estimated; M, presence verified but not quantified, --, not detected]

\begin{tabular}{|c|c|c|c|c|c|c|}
\hline \multirow[b]{2}{*}{ Compound } & \multicolumn{6}{|c|}{ GR-752 } \\
\hline & 3 & 4 & 6 & 7 & 8 & $\begin{array}{c}8 \\
\text { (duplicate) }\end{array}$ \\
\hline 1,4-Dichlorobenzene & -- & -- & E.1 & E.1 & E.1 & -- \\
\hline Acetophenone & E.1 & -- & -- & -- & -- & -- \\
\hline $\mathrm{AHTN}^{1}$ & E. .5 & M & -- & -- & -- & -- \\
\hline Benzophenone & E. 3 & E.1 & -- & E .1 & E.1 & -- \\
\hline $\mathrm{HHCB}^{2}$ & E.1 & $\mathrm{M}$ & -- & -- & -- & -- \\
\hline Indole & E. 2 & & E.1 & .7 & E.1 & -- \\
\hline Deet $^{3}$ & 6.7 & 2.0 & E. 2 & 3.1 & .8 & E.18 \\
\hline Naphthalene & E.1 & -- & -- & -- & E.1 & E.05 \\
\hline $\mathrm{OPEO}^{4}$ & $\mathrm{M}$ & -- & -- & -- & -- & -- \\
\hline para-Cresol & & -- & -- & M & -- & -- \\
\hline Phenanthrene & $\mathrm{M}$ & -- & -- & -- & -- & -- \\
\hline Phenol & E. 2 & .8 & -- & 6 & E.4 & E. 35 \\
\hline $\begin{array}{l}\text { Tri(2-chloroethyl) } \\
\text { phosphate }\end{array}$ & E. 2 & -- & -- & -- & -- & -- \\
\hline $\begin{array}{l}\text { Tri(dichloroisopropyl) } \\
\text { phosphate }\end{array}$ & E.1 & -- & -- & -- & -- & -- \\
\hline Tributyl phosphate & E.2 & -- & -- & -- & -- & -- \\
\hline Triclosan & M & -- & -- & -- & -- & -- \\
\hline $\begin{array}{l}\text { Tri(2-butoxyethyl) } \\
\text { phosphate }\end{array}$ & E 1.4 & -- & -- & -- & -- & -- \\
\hline \multicolumn{7}{|c|}{${ }^{1}$ Acetyl-hexamethyl-tetrahydro-naphthalene } \\
\hline \multicolumn{7}{|c|}{${ }^{2}$ Hexahydrohexamethyl-cyclopentabezopyran } \\
\hline \multicolumn{7}{|c|}{${ }^{3} \mathrm{~N}, \mathrm{~N}$-diethyl-meta-toluamide } \\
\hline \multicolumn{7}{|c|}{${ }^{4}$ Octylphenol, monoethoxy- } \\
\hline
\end{tabular}

Although 20 sites in 6 soil regions were investigated, the lack of water at 8 sites and the random nature of contaminant detection and concentrations prevent an assessment of the performance of the HSTS with respect to the soil characteristics. In addition, the two sites with the most data, GR-750 and GR-752, are in the same soil region. However, some general observations can be made. Although the hydrology that drives these systems was not explicitly investigated, the fact that it was difficult to obtain any water at some sites despite an unusually wet season indicates that water movement through these soils is poor. Several factors may account for the reason that $E$. coli bacteria and other constituents were detected in some piezometers but not in others at a single site. The treatment of wastewater may not be uniform throughout 
the leach-line area and (or) the installation of the piezometer could have interfered with water flow in sand seams, reducing the water available for sampling. Other issues that may affect the results, such as seasonal conditions, evapotranspiration, leach-line construction, system age and maintenance, or nonHSTS sources cannot be addressed with the available data.

Although there are insufficient data (because of the limited number of sites) to make an assessment with respect to soil characteristics, the water-quality and E. coli data indicate that movement of untreated wastewater is occurring at some sites (table 11). The Fulton County sites FN-32 and FN-33 had nitrate concentrations greater than $10 \mathrm{mg} / \mathrm{L}$, indicative of human influence; and FN-32 had chloride concentrations greater than $200 \mathrm{mg} / \mathrm{L}$, which may indicate a wastewater component. It should be noted that these two sites had the sandiest soils of all the sites investigated. Although no other sites had nitrate concentrations greater than $10 \mathrm{mg} / \mathrm{L}$, several other sites had chloride concentrations greater than $200 \mathrm{mg} / \mathrm{L}$ : LI-16,
GR-750, 751 and 752. Although wastewater compounds were sampled at only two sites, some compounds were found at both sites (GR-750 and GR-752). E. coli were found in water from piezometers at three sites, GR-750, GR-752, and LI-16.

The rep-PCR process proved useful in this study in linking the bacteria from HSTS to bacteria found in piezometers at several sites and, at one site, to a curtain drain. The results of the rep-PCR analysis support the water-quality-based indications of movement of wastewater from HSTS to the piezometers. At GR-750, bacteria from the septic system were genetically similar to bacteria in water from the seven piezometers and the curtain drain. Although no water-quality samples were collected from the curtain drain at GR-750, the rep-PCR results on $E$. coli from the drain indicate a link to the HSTS. The distance from the HSTS to the drain, about $10 \mathrm{ft}$ laterally from the leach lines, is greater than that to any of the piezometers. At GR-752 and LI-16, bacteria from the HSTS were genetically similar to bacteria in water from piezometers

Table 11. Summary of water-quality and E. coli data indicating the movement of untreated waste water from home sewage treatment systems to adjacent piezometers.

[>, greater than; mg/L, milligrams per liter; HSTS, home sewage treatment systems; --, no evidence of untreated wastewater movement]

\begin{tabular}{|c|c|c|c|c|c|c|c|}
\hline \multirow{2}{*}{\multicolumn{2}{|c|}{$\begin{array}{l}\text { Piezometer and } \\
\text { distance between } \\
\text { screen and leach } \\
\text { line, in feet }{ }^{\mathrm{a}}\end{array}$}} & \multicolumn{2}{|c|}{ Nitrate concentration ${ }^{b}$} & \multirow{3}{*}{$\begin{array}{c}\begin{array}{c}\text { Chloride } \\
\text { concentration b } \\
>200 \mathrm{mg} / \mathrm{L}\end{array} \\
\mathrm{X}\end{array}$} & \multirow{3}{*}{$\begin{array}{c}\begin{array}{c}\text { Number of } \\
\text { waste-water } \\
\text { compounds } \\
\text { detected }\end{array} \\
--\end{array}$} & \multirow{3}{*}{$\begin{array}{c}\begin{array}{c}\text { E. coli } \\
\text { detected, } \\
\text { any method }\end{array} \\
--\end{array}$} & \multirow{3}{*}{$\begin{array}{l}\text { Indication of a } \\
\text { link to HSTS by } \\
\text { way of } E \text {. coli } \\
\text { and rep-PCR } \\
--\end{array}$} \\
\hline & & \multirow{2}{*}{$\frac{>3 \mathrm{mg} / \mathrm{L}}{\mathrm{X}}$} & \multirow{2}{*}{$\frac{>10 \mathrm{mg} / \mathrm{L}}{X}$} & & & & \\
\hline $\mathrm{FN}-32,1$ & 6 & & & & & & \\
\hline FN-32, 2 & 9 & X & X & $\mathrm{X}$ & -- & -- & -- \\
\hline $\mathrm{FN}-33,1$ & 5 & $\mathrm{X}$ & $X$ & -- & -- & -- & -- \\
\hline GR-750, 1 & 5 & -- & -- & $X$ & -- & $\mathrm{X}$ & \\
\hline GR-750, 3 & 5 & -- & -- & $\mathrm{X}$ & 11 & $\mathrm{X}$ & $\mathrm{X}^{\mathrm{c}}$ \\
\hline GR-750, 4 & 5 & -- & -- & $\mathrm{X}$ & 8 & $\mathrm{X}$ & $X^{c}$ \\
\hline GR-750, 5 & 5 & -- & -- & $\mathrm{X}$ & 4 & -- & -- \\
\hline GR-750, 6 & 5 & -- & -- & $\mathrm{X}$ & 2 & -- & -- \\
\hline GR-750 7 & 5 & -- & -- & $X$ & 3 & $X$ & $X^{\mathrm{c}}$ \\
\hline GR-750, 8 & 5 & -- & -- & $X$ & 16 & $\mathrm{X}$ & $\mathrm{X}^{\mathrm{c}}$ \\
\hline GR-750, 9 & 7 & -- & -- & -- & -- & $\mathrm{X}$ & $\mathrm{X}^{\mathrm{c}}$ \\
\hline GR-751, 2 & 13 & -- & -- & $\mathrm{X}$ & -- & -- & -- \\
\hline GR-752, 1 & 5 & -- & -- & $X$ & -- & $X$ & -- \\
\hline GR-752, 3 & 6 & -- & -- & $X$ & 15 & $X$ & $X$ \\
\hline GR-752, 4 & 7 & -- & -- & $\mathrm{X}$ & 5 & -- & -- \\
\hline GR-752, 6 & 17 & -- & -- & -- & 3 & -- & -- \\
\hline GR-752, 7 & 11 & -- & -- & $X$ & 6 & $X$ & $X$ \\
\hline GR-752, 8 & 23 & $X$ & -- & -- & 6 & -- & -- \\
\hline GR-753 1 & 5 & -- & -- & -- & -- & -- & -- \\
\hline GR-753, 2 & 13 & $X$ & -- & -- & -- & -- & -- \\
\hline LI-16, 1 & 5 & -- & -- & -- & -- & $\mathrm{X}$ & -- \\
\hline LI-16, 2 & 9 & -- & -- & $X$ & -- & -- & -- \\
\hline LI-16, 3 & 6 & -- & -- & -- & -- & $\mathrm{X}$ & $\mathrm{X}$ \\
\hline
\end{tabular}


at each site. However, in a recent study (as yet unpublished) by the authors of this report, the rep-PCR method identified genetically similar bacteria in multiple samples from unrelated HSTSs, indicating that rep-PCR linkage is not positive proof of origin from a single household (unpublished data on file at the USGS, Ohio Water Science Center). Thus, the rep-PCR data provide additional evidence of a link between the various samples and the related HSTS, but not proof positive.

\section{Limitations of the Pilot Study and Suggestions for Future Investigations}

This pilot study was designed with three goals in mind: (1) to examine the effects of soil characteristics on HSTS, (2) to obtain a better understanding of the quality of water exiting HSTSs, and (3) to investigate the usefulness of a genetic fingerprinting approach in determining the source of any fecal-related bacteria found. The small number of sites from which water samples were obtained prevented any assessments with respect to soil characteristics and limited the water-quality interpretations; and, although some potential usefulness of genetic fingerprinting was shown, the small number of samples is by no means a definitive proof of the method. Factors that could affect the results of this pilot study that were not addressed include the regional hydrology, preferential flow paths in the soils, seasonal and (or) temporal influences (such as evapotranspiration), and HSTS design, installation, and maintenance methods. In addition, other potential sources of constituents such as wastewater compounds were not addressed. These unaddressed factors affect the results of this study because sites where no samples could be collected or bacteria were not detected should not be considered to be any better than the sites where bacteria were detected.

Although the output of HSTS will be fairly constant, soil conditions - and therefore water treatment-may be affected by seasonal changes in temperature, precipitation, and so forth. In addition, seasonal changes in the hydrology will occur regardless of the output from HSTS. For example, ground-water levels and pumping (domestic wells) fluctuate, possibly affecting local ground-water flow directions. Patterns of water movement within the soil around the systems may change in response to drought or excessive precipitation. The importance of seasonal changes on the waste treatment in HSTS is poorly known; additional studies that investigate the extent, if any, of seasonal or temporal changes on the migration of untreated wastewater from HSTS would be useful.

The rep-PCR tool for microbial source tracking (MST) provided evidence that $E$. coli bacteria traveled at least $3 \mathrm{ft}$ laterally_and, in one case, $10 \mathrm{ft}$ laterally_from the HSTS. However, this evidence is no proof positive of transport from a specific HSTS because of the chance that other local households could carry the same E. coli (unpublished data on file at the USGS Ohio Water Science Center). Other approaches to MST (those that detect host-specific DNA markers; Field and others, 2003) could potentially yield general information about whether the E. coli originated from human or nonhuman sources but would not yield information about a specific source household. Augmenting evidence from rep-PCR and from water-quality data with hydrologic data and evidence from other MST tools would allow for a more confident interpretation of data in future research.

\section{Summary}

The soils in Ohio generally are considered poor for the use of home sewage treatment systems (HSTS); however, the success or failure of the systems to adequately treat sewage is unclear because there are often no visible signs of failure. This study was done by the U. S. Geological Survey (USGS), in cooperation with the Ohio Department of Health, to obtain a better understanding of the effects of soil characteristics on the quality of water exiting HSTS and investigate the usefulness of genetic fingerprinting analysis in determining the source of any fecal-related bacteria found. Sites for this investigation were selected on the basis of poor soils but no visible evidence of failure. During summer and fall 2003 and early winter 2004, water samples from piezometers installed near active leach lines at 20 locations in 7 Ohio counties were analyzed for nutrients, chloride, and E. coli bacteria. Two sites were revisited and additional water samples were collected for nitrogen isotopes and wastewater compounds. At a few selected sites, E. coli bacteria were analyzed with rep-PCR to track the source of the bacteria.

Despite an unusually wet year, water could not be obtained from 8 of the 20 sites; at 5 of the remaining 12 sites, water could be obtained from only 1 piezometer. This limited data set prevented any analysis of soil characteristics with respect to water quality. However, the water-quality data collected indicated influences from HSTS at some sites. At two sites in Fulton County (FN-32 and FN-33), nitrate concentrations exceeded $10 \mathrm{mg} / \mathrm{L}$, indicating some human influence. Chloride concentrations in excess of $200 \mathrm{mg} / \mathrm{L}$, which may indicate some influence of wastewater, were found at one Fulton County site (FN-32), three Greene County sites (GR-750, GR-751 and GR-752), and one Licking County site, (LI-16). E. coli were found in water in piezometers at GR-750, GR-752, and LI-16. At each of these three sites, the genetic fingerprinting of $E$. coli was useful in showing evidence of a link between bacteria from water in the piezometers to bacteria from the HSTS. Furthermore, at GR-750, water in the curtain drain located $10 \mathrm{ft}$ from the leach lines contained bacteria genetically similar to bacteria from the HSTS. At two sites, GR-750 and GR-752, water samples also were analyzed for nitrogen isotopes and wastewater compounds. The nitrate concentrations were too low for accurate isotopic analysis; however, some wastewater compounds were found at both sites. 
The water quality, bacteria, and rep-PCR data indicate that at some sites untreated wastewater, and likely bacteria, moved from the HSTS to piezometers installed several feet from the leach lines and at depths of 4 to $8 \mathrm{ft}$. In addition, in one case, there is indication that bacteria reached a curtain drain $10 \mathrm{ft}$ from the leach lines.

\section{Acknowledgments}

The authors thank personnel at the State and County health departments for their assistance in locating sites and Tim Gerber, Ohio Department of Natural Resources, and his colleagues for soil analyses at select sites throughout the state. The authors also thank the numerous individual property owners who allowed access to their yards and HSTS.

\section{References Cited}

Baker, B.B., Wallrabenstein, L.,K., Richards, R.P., and Creamer, N.L., 1989, Nitrate and pesticides in private wells of Ohio-A state atlas: Tiffin, Ohio, Water Quality Laboratory, Heidelberg College, part 1, $71 \mathrm{p}$.

Bacterial Barcodes, 2004, DiversiLab protocols and application profiles, accessed December 8, 2004, at http://www. bacbarcodes.com/dl_application_profile.htm

Brady, N.C. and Weil, R.R., 1999, The nature and properties of soils (12th ed.): Upper Saddle River, N.J., Prentice Hall, $881 \mathrm{p}$.

Cashell, D.H. and Kirk, Scott, 2003, Monthly water inventory report for Ohio, December 2003: Ohio Department of Natural Resources, Division of Water, $2 \mathrm{p}$.

Caugant, D.A., Levin, B.R., and Selander, R.K., 1981, Genetic diversity and temporal variation in the E. coli population of a human host: Genetics, v. 98, p. 467-490.

Cole, D., Long, S.C., and Sobsey, M.D., 2003, Evaluation of F+RNA and DNA coliphages as source-specific indicators of fecal contamination in surface waters: Applied and Environmental Microbiology, v. 69, no. 11, p. 6507-6514.

Dumouchelle, D.H., Schalk, C.W., Rowe, G.L., and de Roche, J.T., 1993, Hydrogeology, simulated ground-water flow, and ground-water quality, Wright-Patterson Air Force Base, Ohio: U.S. Geological Survey Water-Resources Investigations Report 93-4047 152 p.

Field, K.G., Bernhard, A.E., and Brodeur, T.J., 2003, Molecular approaches to microbiological monitoring-fecal source detection: Environmental Monitoring and Assessment, vol. 81 pp 313-326.
Fishman, M.J., ed., 1993, Methods of analysis by the U.S. Geological Survey National Water Quality LaboratoryDetermination of inorganic and organic constituents in water and fluvial sediments: U.S. Geological Survey OpenFile Report 93-125, 217 p.

Fishman, M.J., and Friedman, L.C., 1989, Methods for determination of inorganic substances in water and fluvial sediments: U.S. Geological Survey Techniques of WaterResources Investigations, book 5, chap. A1, 545 p.

Francy, D.S., Bushon, R.N, Luzano, E.J, Brady, A.M.G., Kephart, C.M, and Stoeckel, D.M., 2004, Quality assurance/quality qontrol manual, Ohio District Microbiology Lab, accessed on December 9, 2004, at http://oh.water.usgs. gov/micro/qcmanual/manual.html

Hem, J.D., 1989, Study and interpretation of the chemical characteristics of natural water ( $3 \mathrm{~d}$ ed.): U.S. Geological Survey Water-Supply Paper 2254, 263 p.

Garner, D.E., Ritchie, A., and Siegenthaler, V.L., 1978, Soil survey of Greene County, Ohio: U.S. Department of Agriculture, Soil Conservation Service, 105 p., 53 sheets, scale $1: 15,840$.

Gillespie, J.L., and Dumouchelle, D.H., 1989, Ground-water flow and quality near the upper Great Lakes connecting channels, Michigan: U.S. Geological Survey WaterResources Investigation Report 88-4232, 82 p., 5 plates.

Jagucki, M.L., and Darner, R.A., 2001, Ground-water quality in Geauga County, Ohio-Review of previous studies, status in 1999, and comparison of 1986 and 1999 data: U.S. Geological Survey Water-Resources Investigations Report 01-4160, $61 \mathrm{p}$.

Johnson, L.K., Brown, M.B., Carruthers, E.A., Ferguson, J.A., Dombek, P.E., and Sadowsky, M.J., 2004, Sample size, library composition, and genotypic diversity among natural populations of Escherichia coli from different animals influence accuracy of determining sources of fecal pollution: Applied and Environmental Microbiology, v. 70, no. 8, p. 4478-4485.

Kariuki, S., Gilks, C., Kimari, J., Obanda, A., Muyodi, J., Waiyaki, P., and Hart, C.A., 1999, Genotype analysis of Escherichia coli strains isolated from children and chickens living in close contact: Applied and Environmental Microbiology, v. 65 , no. 2, p. 472-476.

Mancl, Karen, and Slater, David, 2001, Suitability assessment of Ohio's soils for soil-based wastewater treatment: Ohio Journal of Science, v. 101, no. 3/4, p.48-56.

Matanzo, F., Stone, Jr., K.L., Thompson, D., and Wenner, K.H., 1969, Soil survey of Delaware County, Ohio: U.S. Department of Agriculture, Soil Conservation Service, 71 p., 56 sheets, scale 1:15,840. 
McLellan, S.L., 2004, Genetic diversity of Escherichia coli isolated from urban rivers and beach water: Applied and Environmental Microbiology, v. 70, no. 8, p. 4658-4665

McLoda, N.A., and Parkinson, R.J., 1980, Soil survey of Franklin County, Ohio: U.S. Department of Agriculture, Soil Conservation Service, 188 p., 68 sheets, scale $1: 15,840$.

Miller, K.E., and Robbins, R.A., 1994, Soil survey of Hardin County, Ohio: U.S. Department of Agriculture, Soil Conservation Service, 180 p., 66 sheets, scale 1:15,840.

National Oceanic and Atmospheric Administration, 2003a, Climatological Data, Ohio, July 2003: Asheville, N.C., National Climatic Data Center, vol. 108, no. 07.

National Oceanic and Atmospheric Administration, 2003b, Climatological Data, Ohio, August 2003: Asheville, N.C., National Climatic Data Center, vol. 108, no. 8.

National Oceanic and Atmospheric Administration, 2003c, Climatological Data, Ohio, September 2003: Asheville, N.C., National Climatic Data Center, vol. 108, no. 9.

National Oceanic and Atmospheric Administration, 2003d, Climatological Data, Ohio, October 2003: Asheville, N.C., National Climatic Data Center, vol. 108, no. 10.

National Oceanic and Atmospheric Administration, 2003e, Climatological Data, Ohio, November 2003: Asheville, N.C., National Climatic Data Center, vol. 108, no. 11.

National Oceanic and Atmospheric Administration, 2003f, Climatological Data, Ohio, December 2003: Asheville, N.C., National Climatic Data Center, vol. 108, no. 12.

National Oceanic and Atmospheric Administration, 2004, Climatological Data, Ohio, January 2004: Asheville, N.C., National Climatic Data Center, vol. 109, no. 1.

Ohio Department of Natural Resources, Division of Real Estate and Land Management, 1975-87, Soil mapping units, accessed on October 19, 2004, at http://www.ohiodnr. com/gims

Ohio Department of Natural Resources, Division of Soil and Water Conservation, 2004, Introduction to the soils regions of Ohio, accessed on October 20, 2004, at http://www.dnr. state.oh.us/soilandwater/soils/soilreg1.htm

Panno, S.V., Hackley, K.C., Hwang, H.H., Greenburg, S., Krapac, I.G., Landsberger, S., and O'Kelly, D.J., 2002, Source identification of sodium and chloride contamination in natural waters-Preliminary results: Proceedings of the 12th annual Illinois Groundwater Consortium conference, accessed February, 17, 2004, at http://www.siu.edu/orda/ igc/proceedings/02/panno.pdf
Rademakeer, J., and de Bruijn, F.J., 1997, Charcterization and classification of microbes by REP-PCR genomic fingerprinting and computer assisted pattern analysis, in CaetanoAnolles, G., Gresshoff, P.M., eds., DA markers-Protocols, applications, and overviews: New York, Wiley-Liss, p. 151-172.

Redmond, C.E., and Graham, T.E., 1986, Soil survey of Knox County, Ohio: U.S. Department of Agriculture, Soil Conservation Service, 213 p., 66 sheets, scale 1:15,840

Shindel, H.L., Mangus, J.P., and Frum, S.R., 2003, Water resources data, Ohio, water year 2002: U.S. Geological Survey, Water-Data Report OH-02-2 p. 216-242.

U.S. Bureau of the Census, 2000, Census 2000 TIGER/line data, accessed on October 19, 2004, at http://www.esri. com/data/download/census2000_tigerline/

U.S. Department of Agriculture, Natural Resources Conservation Service, 1997, National map unit interpretation records (MUIR), accessed on October 19, 2004, at http://soils.usda. gov/survey/nmuir/index.html

U.S. Department of Agriculture, Natural Resources Conservation Service, 2000, Soil Survey Geographic database (SSURGO), accessed on October 19, 2004, at http://www. ncgc.nrcs.usda.gov/branch/ssb/products/ssurgo/

U.S. Environmental Protection Agency, 2001, Method 1602-Male-specific (F+) and somatic coliphage in water by single agar layer (SAL) procedure, accessed on December 9, 2004, at http://www.epa.gov/nerlcwww/1602ap01.pdf

U.S. Environmental Protection Agency, 2000, Improved enumeration methods for the recreational water quality indicators-Enterococci and Escherichia coli: Washington D.C., Office of Science and Technology, 27 p.

U.S. Environmental Protection Agency, 2004, List of drinking water contaminants \& MCLs, accessed on October 20, 2004, at http://www.epa.gov/safewater/mcl.html

Wildermuth, R., Lee, W.D., Paschall, A.H., and Steele, J.G, 1930, Soil survey of Licking County, Ohio: U.S. Department of Agriculture, Bureau of Chemistry and Soils, 57 p., 1 sheet, scale 1:62,500.

Whittam, T.S., 1989, Clonal dynamics of Escherichia coli in its natural habitat: Antonie van Leeuwenhoek, v. 55, p. 23-32.

Yang, H.H., Vonopal, R.T., Grasso, D., and Smets, B.F., 2004, High diversity among environmental Escherichia coli isolates from a bovine feedlot: Applied and Environmental Microbiology, v. 70, no. 3, p. 1528-1536. 
Zaugg, S.D., Smith, S.G., Schroeder, M.P., Barger, L.B., and Burkhardt, M.R., 2002, Methods of analysis by the U.S. Geological Survey National Water Quality LaboratoryDetermination of wastewater compounds by polystyrenedivinylbenzene solid-phase extraction and capillary-column gas chromatography/mass spectrometry: U.S. Geological Survey Water-Resources Investigations Report 01-4186, $37 \mathrm{p}$. 

Appendixes 


\section{Appendix 1. Technical Details of E. coli Typing by Use of rep-PCR}

\section{Cultivation and Isolation}

From each sample, well-separated yellow colonies were picked from mTEC agar with a sterile toothpick, cultivated overnight in tryptic soy broth, and amended with glycerol (a cryoprotectant) to a final concentration of 40 percent (volume per volume). Thus isolated and grown out, cultures were held at $-70^{\circ} \mathrm{C}$ to await further processing. Processing resumed by streaking each culture for purity onto eosin methylene blue agar (EMB; Becton, Dickinson, and Company, Sparks, Md.) and, if the culture exhibited characteristic green sheen, single colonies were picked to Luria Bertani broth (LB; Becton, Dickinson, and Company, Sparks, Md.) for cultivation of pure cultures. One aliquot of pure culture was amended with glycerol to a final concentration of 40 percent (volume per volume) glycerol and archived at $-70^{\circ} \mathrm{C}$. From the remaining pure culture, $10 \mu \mathrm{L}$ was streaked onto tryptic soy agar and cultivated. Streaks were used as starting material for DNA extraction with genomic DNA extraction kits (Mo-Bio, Carlsbad, Calif.) according to manufacturer's recommendations. Extracted and purified DNA was resuspended in TrisEDTA buffer. The concentration of each extract was measured by means of Pico Green stain (Molecular Probes, Eugene, Oreg.), and DNA samples were diluted with Tris-EDTA buffer to a standard $50 \mathrm{ng} / \mu \mathrm{L}$ for use as rep-PCR template. DNA extracts, normalized to $50 \mathrm{ng} / \mu \mathrm{L}$, were held at $-70^{\circ} \mathrm{C}$ until needed.

\section{Generation of PCR Products}

The rep-PCR protocol by use of Box primers (Box-PCR) was done with the Diversilab system (Spectral Genomics, Austin, Tex.) in accordance with company recommendations. BOX A1R primer (5'-CTA Cgg CAA ggC gAC gCT gAC g-3') and buffer were obtained as components of proprietary reagent kits. AmpliTaq polymerase (Promega, Madison, Wis.) was added to Diversilab reagents for the PCR. The PCR was done in sets containing 10 test isolates, a replicate (either within-run or outside-run replicate analysis), a repeated-measure positive control (E. coli ATCC 25922), and a negative control containing no template. As many as four sets were done simultaneously in eight-tube strips. PCR temperature cycling was done in an Eppendorf MasterCycler with cycling conditions as specified by Diversilab (denaturing at $94^{\circ} \mathrm{C}$ for 2 minutes; 35 cycles of $94^{\circ} \mathrm{C}$ for 30 seconds, $50^{\circ} \mathrm{C}$ for $30 \mathrm{sec}-$ onds, and $70^{\circ} \mathrm{C}$ for 90 seconds; final extension for 3 minutes at $\left.70^{\circ} \mathrm{C}\right)$.

Separation and visualization.-The rep-PCR products were held at $-20^{\circ} \mathrm{C}$ for analysis within 5 days. The Diversilab system integrates the Agilent Bioanalyzer (Palo Alto, Calif.) to separate PCR amplification products by microcapillary gel electrophoresis, referred to by the manufacturer as "lab on a chip" technology. One microliter of PCR product from each isolate included in a run (the 10 test isolates, the replicate, and the positive control) were run together on each 12-well chip. Each well contained internal 150 and 7,000 base pairs (bp) standards, and each chip included a 13th well in which a standard-size DNA ladder was run. Negative-control blank PCR products were tested for lack of PCR product by separation with traditional agarose gel electrophoresis, staining with ethidium bromide, and visualization on a UV transilluminator.

The output from the Bioanalyzer is an electropherogram. The electropherogram is a graph of DNA present in the effluent from the microcapillary electrophoresis channel: peaks are present at times when DNA bands come out of the channel. For easier visualization, the electropherogram is converted into a synthetic image that looks like the DNA profile that one would get from traditional agarose gel electrophoresis. Image analysis was by use of proprietary Diversilab software. Output consisted of a dendogram created from unweighted pairedgroup means by means of arithmetic-averages (UPGMA) clustering of Pearson similarity coefficients.

The rep-PCR method measures an index of genetic similarity but does not give information on species, so operational taxonomic units (OTU) were defined to assign genetically similar isolates to groups; isolates in an OTU had at least 96 percent genetic similarity by the procedures used. At least 10 percent of each OTU were tested to confirm that the OTU belonged to the species $E$. coli. Because of the clonal nature of $E$. coli populations (Whittam, 1989) and the diversity of $E$. coli reported in literature studies (Caugant and others, 1981; Johnson and others, 2004; Kariuki and others, 1999; McLellan, 2004; and Yang and others, 2004) all E. coli isolates belonging to the same OTU were assumed to have come from the same source. By extension, the same is true for the isolates that did not confirm as E. coli. This assumption would be violated if humans (HSTS isolates) shared the same OTU with their pets (surface feces isolates). In no case, however, did an isolate of HSTS origin share the same OTU with an isolate from an alternate fecal source. The assumption also would be violated if multiple HSTS carry isolates of the same OTU. In no case, however, did an OTU include isolates from more than one HSTS.

Classification of unknowns.-Similarity within the repeated-measures data collection was used to assign each isolate to an operational taxonomic unit (OTU). Briefly, the similarity of repeated measurements on the positive-control isolate was used as a criterion to describe variability in the method, and any isolates that were more similar than the repeated-measures criterion were considered indistinguishable members of the same OTU (fig. 6). In cases where a water-isolated E. coli belonged to an OTU that also included HSTS or alternate-source $E$. coli, the water-isolated $E$. coli was classified as being from that source. 
Confirmation steps.-Ten percent of membership in each OTU, at least one member, was tested to confirm that the members of an OTU belonged to the species E. coli. Tests included lack of urease activity, fermentation of lactose in EC broth, production of indole when grown in tryptone, and failure to grow on citrate (U.S. Environmental Protection Agency, 2000).

Quality control.-The isolates were run as five "jobs," labeled A through E. Within each job, all analyses were done with the same PCR reagent mix, simultaneous PCR in the 96-well thermal cycler, and sequential PCR-product separation on the Bioanalyzer. Each job included as many as 49 individual PCR tubes - one was a reagent blank, at least one (generally two) was a repeated measures amplification of the positive control, E. coli ATCC 25922, and at least one (generally two) was a replicate amplification of a test $E$. coli isolate. PCR replicates were done both between jobs and within job.

The 48 test isolates were run in batches of 12 on the Bioanalyzer with four analysis chips. Each well of the Bioanalyzer chip contained internal 150- and 7,000-bp size standards. Each chip also included a 13th well in which a standard-size DNA ladder was run to allow accurate integration of PCR-product sizes between the 150- and 7,000-bp standards.

Each job was evaluated for quality control upon data generation. Individual results were checked for correct identification of size-standard peaks, for spikes, and for other analytical problems. Within each job, the repeated-measures isolates (ATCC 25922) were checked to ensure consistency with prior measurements, and within-job replicates were checked for internal consistency. After the entire data set was compiled, the between-run replicates also were checked for consistency.

Upon analysis, it was found that all nine ATCC repeated-measures isolates had high similarity (greater than 97 percent), both among themselves and with a group of 22 previously run repeated measures. Of the 10 duplicate analyses of test isolates (4 within job and 6 between jobs), 8 pairs had similarity greater than or equal to the repeated measures observation, and 2 had slightly lower similarity. Blanks were tested for product formation in a single agarose gel, and none showed formation of PCR products. On the basis of these quality-control checks, all data in the final database were considered suitable for further analysis.

Critical to the interpretation of these data is defensible and repeatable assignment of isolates to OTU. This step is done with substantial professional judgment. To ensure that OTU assignments were reasonable, the OTU assignment method and data were sent to a colleague for review. Of the 53 OTU assignments made, 6 were questioned in the review. In each case, the recommendation was that two or more OTU could be combined because limited evidence existed to justify the assignment of multiple OTU. The recommended combinations of OTU would not have affected study interpretations-the same associations among E. coli types from HSTS, non-HSTS sources, piezometers, and curtain drains hold with either set of OTU assignments. 


\section{Appendix 2. Details on Unsampled Phase 2 Sites}

The site in Fairfield County was in soil region 5, the Bennington-Cardington-Centerburg series (figs. 1, 2). The soils at the site were investigated in greater detail by the ODNR, and are described as silt and clay loams that are well drained with moderately slow permeability (Tim Gerber, Ohio Department of Natural Resources, written commun., 2004). Piezometers were installed at various depths at this site on two dates (table 3). The October monthly precipitation at the Lancaster station was 1.54 in.; the November monthly precipitation was 3.16 in. The day before the October sampling, the Lancaster, Ohio, station recorded 0.84 in. of precipitation; the day of sampling in November, the station recorded 0.43 in. of precipitation (National Oceanic and Atmospheric Administration, $2003 \mathrm{~d}, \mathrm{e})$. The leach field at the site was installed on a slope and had a single set of leach lines and no curtain drain. The first pair of piezometers was installed about $4 \mathrm{ft}$ downslope of the last leach line, at about the midpoint of the line. The screens were set from 4 to $8 \mathrm{ft}$ and 9 to $13 \mathrm{ft}$ deep. The second set of piezometers was installed at about the same location and at an angle such that the screens were about 7.2 $\mathrm{ft}$ directly beneath the leach line. In both cases, sampling was attempted the day after installation, but no water was obtained from any of the piezometers.

The Greene County site was in soil region 4, the Miamian-Kokomo-Eldean series (figs. 1, 2) in the Eldean-OckleyWea association. This soil association is described as welldrained loams and silty loams with moderate to moderately slow permeability in the upper zones and rapid permeability at depth (Garner and others, 1978). Two piezometers were installed at this site in late July (table 3). The July monthly precipitation at the Xenia station was $6.27 \mathrm{in}$., 1.65 in. greater than normal; during the two weeks before sampling the precipitation was 1.65 in. (National Oceanic and Atmospheric Administration, 2003a). At the time of installation, the ground was saturated but there was no ponded water. The system had a diverter box but no curtain drain. The diverter box was checked, and only one line was active. The piezometers were installed about $3.5 \mathrm{ft}$ from the active leach line, close to the start of the line (roughly 6-8 ft from the diverter box). The screens were set from 4 to $8 \mathrm{ft}$ and 12 to $16 \mathrm{ft}$ deep. Sampling was attempted the day after installation; however, both piezometers were dry.

The Hardin County sites were in soil region 3, the Blount-Pewamo-Glynwood series (figs. 1, 2). Both sites are in the Blount-Pewamo soil association. This soil association is described as silt and silty-clay loams with somewhat-poor to very poor drainage and slow to moderately slow permeabilities (Miller and Robbins, 1994). Piezometers were installed at two sites in early August (table 3). The July monthly precipitation at the Kenton, Ohio, station was 6.85 in., 2.91 in. greater than normal; during the two weeks before sampling the precipitation was 2.51 in. (National Oceanic and Atmospheric Administration, 2003a). At the western site (fig. 2), the diverter box was so full of water that both sets of leach lines were effectively active. Three piezometers were installed. A shallow (screened from 4 to $8 \mathrm{ft}$ ) and deep pair (screened from 12 to 16 $\mathrm{ft}$ ) were placed about $4 \mathrm{ft}$ from the last leach line of the "inactive" field (drilling access to the "active" field was limited). The third piezometer, screened from 0 to $4 \mathrm{ft}$, was installed about $5 \mathrm{ft}$ from the diverter box, between the two leach fields. At the eastern site (fig. 2) the diverter box was buried, so it was not possible to identify the active leach field. Two piezometers were installed about $4 \mathrm{ft}$ from the last leach line of the field marked as active on the permit. At both locations, sampling was attempted the day after installation; however, all piezometers were dry.

The Hocking County site was in soil region 10, the Shelocta-Brownsville-Latham-Steinsburg series (figs. 1, 2) in the Chagrin-Otwell-Wheeling association. The soils at the site were investigated in greater detail by the ODNR and are described as silt and clay loams that are well to moderately well drained with moderate to moderately slow permeability (Tim Gerber, Ohio Department of Natural Resources, written commun., 2004). The October monthly precipitation in the area was only slightly above normal, but two stations in Hocking Co. (Enterprise and Laureville) recorded 1.53 and 1.86 in., respectively, on November 11, a week before the piezometers were installed (National Oceanic and Atmospheric Administration, 2003d, e). At the time of installation, the ground was so saturated that the drilling rig could not be used. The piezometers were installed by hand, which limited the depth of installation. The system had no diverter box or curtain drain. Two piezometers were installed about $4 \mathrm{ft}$ from the midpoint of the last leach line; both were screened from 4 to $8 \mathrm{ft}$ deep. Sampling was attempted the day after installation; however, both peizometers were dry.

The Licking County site was in soil region 5, the Bennington-Cardington-Centerburg series (figs. 1,2) in the Alexandria silt loam (Wildermuth and others, 1930). These soil series are formed on glacial tills; they are somewhat poorly or moderately well drained and have slow to moderately slow permeabilities (McLoda and Parkinson, 1980; Redmond and Graham, 1986). The piezometers were installed mid-January. On January 4-5, with maximum temperatures well above freezing, 3.35 in. of precipitation was recorded (Newark Water Works station, National Oceanic and Atmospheric Administration, 2004); however, after January 5, the maximum temperatures were generally below freezing, and only 0.48 in. of precipitation was recorded at the station. The leach field was uphill from the tank in an area inaccessible to the rig, so the piezometers were installed by hand, which limited the depth of installation. The system had a lift pump and diverter box but no curtain drain. The diverter box was checked to determine the active line. Two piezometers were installed about $2 \mathrm{ft}$ from the end of the first leach line and were screened from 3.5 to 
7.5 and 4 to $8 \mathrm{ft}$ deep. Sampling was attempted the day after installation; however, both piezometers were dry.

The Knox County sites were in soil region 8, the Westmoreland-Homewood-Loudonville series (figs. 1, 2). Both sites are in the Homewood-Loudonville-Titusville association. This soil association is described as well drained to moderately well drained soils formed on till plains and moraines. Both sites are in areas mapped as silt loams with moderate permeablities (Redmond and Graham, 1986). Piezometers were installed at two sites in late August (table 3). The August monthly precipitation at the Greer and Danville stations were 4.31 in. and 5.0 in., respectively. The precipitation at the Danville station was 1.16 in. greater than normal (no data was given for the Greer station); during the two weeks before sampling, the precipitation was about $1.4 \mathrm{in}$. at both stations (National Oceanic and Atmospheric Administration, 2003b). The leach field at the northeasternmost site (fig. 2) was installed on a slope. The system had a diverter box but no curtain drain. The diverter box was checked to determine the active lines. Two piezometers were installed about $4 \mathrm{ft}$ from the end of the first active leach line. Bedrock was encountered at about $8.25 \mathrm{ft}$, so the piezometers were screened from 3 to 7 and 4 to $8 \mathrm{ft}$ deep. The leach field at the central site (fig. 2) was also installed on a slope, with a diverter box and no curtain drain. The diverter box was checked to determine the active line. Two piezometers were installed about $15 \mathrm{ft}$ and about $4 \mathrm{ft}$ from the active line, about $15 \mathrm{ft}$ from the diverter box. Bedrock was encountered at about $12 \mathrm{ft}$; the piezometers were screened from 4 to 8 and 8 to 12 feet deep. Sampling was attempted the day after installation; however, all piezometers were dry. 


\section{Appendix 3. Details on Sampled Sites, Phases 2 and 3}

The Delaware County site, DL-69, was in soil region 5, the Bennington-Cardington-Centerburg series (figs. 1, 2), and in the Bennington-Pewamo-Cardington soil association. This soil association is described as moderately well drained to very poorly drained silt loams with moderately slow permeability (Matanzo and others, 1969). The site had two leach fields, a diverter box, and a curtain drain. In mid-October, two piezometers were installed between the end of the active leach field and the curtain drain (table 4). During the month (mid-September to mid-October) before installation, 4.9 in. of precipitation was recorded at a nearby station in northern Franklin County; during the two weeks before sampling the precipitation was 1.31 in. (National Oceanic and Atmospheric Administration, 2003d, 2003e). The ground in the vicinity of the piezometers was saturated, but there was no ponded water. The shallow piezometer was between two active lines and about $4.6 \mathrm{ft}$ from the end of the leach field and was screened from 4 to $8 \mathrm{ft}$ deep. The deep piezometer was next to the shallow piezometer but closer to the leach field, being about 3.8 $\mathrm{ft}$ from the field and screened from 9 to $13 \mathrm{ft}$ deep. Sampling was attempted the day after installation. The shallow piezometer was dry. About $100 \mathrm{~mL}$ of water was collected from the deep piezometer, sufficient only for the bacteria analysis (table 4).

The Fulton County sites, FN-32 and FN-33, are in soil region 1, the Hoytville-Nappanee-Paulding-Toledo series (figs. 1,2). The soils at both sites were investigated in detail by ODNR. Piezometers were installed in mid-November (table 4). The October monthly precipitation at the Wauseon water plant station was 2.95 in., a departure from normal of only 0.36 in.; during the two weeks before sampling the precipitation was only 0.19 in. (National Oceanic and Atmospheric Administration, 2003d, 2003e). The western site, FN-32 (fig. 2), was mapped as a moderately well drained soil with sandy textures and rapid permeability (Tim Gerber, Ohio Department of Natural Resources, written commun., 2004). The site had two sets of leach lines with a diverter box but no curtain drain. Two piezometers, screened from 4 to $8 \mathrm{ft}$ and 8 to 12 $\mathrm{ft}$ deep, were installed about $4 \mathrm{ft}$ from an active leach line. Water samples for chloride, nutrient and bacteria analyses were collected from both piezometers the day after installation. The eastern site, FN-33, was mapped as a moderately well drained soil with sandy textures and rapid permeability above 40-in. depth; a much finer texture and slow to very slow permeability was found below 40-in. depth (Tim Gerber, Ohio Department of Natural Resources, written commun., 2004). The site had two sets of leach lines with a diverter box but no curtain drain. Both sets of leach lines were active. Two piezometers, screened from 4 to $8 \mathrm{ft}$ and 8 to $12 \mathrm{ft}$ deep, were installed about $4 \mathrm{ft}$ from an active leach line. Water samples for chloride, nutrient and bacteria analyses were collected from the shallow piezometer the day after installation; the deep piezometer was dry.
The Franklin County site, FR-522, is in soil region 4, the Miamian-Kokomo-Eldean series (figs. 1, 2). The site is mapped as the Miamian silty clay loam, which is described as well drained with moderately slow permeability (McLoda and Parkinson, 1980). In late January, two piezometers were installed (table 4). The January monthly precipitation at the Columbus, Ohio, Airport station was 5.08 in., 2.55 in. greater than normal; although 3.58 in. fell over January 3-4, the precipitation during the two weeks before sampling was only 0.41 in. (National Oceanic and Atmospheric Administration, 2004) The site had a single set of leach lines. No curtain drain was shown on the property sketch or noted during the site visit, but discussions with the owner and neighbor reveal that a drain was installed after the system had problems. The piezometers were installed about $4 \mathrm{ft}$ from a leach line. The shallow piezometer was screened from 4 to $8 \mathrm{ft}$ deep, and the deep piezometer was screened from 8 to $12 \mathrm{ft}$ deep. Sampling was attempted the day after installation. Only about 150 to $200 \mathrm{~mL}$ of water was collected from each of the piezometers, sufficient only for the bacteria analysis (table 4).

The four Greene County sites, GR-750, GR-751, GR-752, and GR-753 are all in soil region 4, the MiamianKokomo-Eldean series (figs. 1, 2). Detailed soil investigations were conducted by ODNR at GR-750 and GR-752. At GR-750, the loess-derived soils were described by ODNR as being somewhat poorly drained with moderately slow or slow permeability; glacial till was observed at about 50 in. At GR-752, the soils were described by ODNR as being very poorly drained with moderately slow or slow permeability; glacial till was not observed (T. Gerber, Ohio Department of Natural Resources, written commun., 2004). The July monthly precipitation at the Xenia, Ohio, station was 6.27 in., 1.65 in. greater than normal; during the two weeks before sampling the precipitation was 1.65 in. (National Oceanic and Atmospheric Administration, 2003a).

GR-750.-Piezometers were installed in late July. The system has two sets of leach lines with a diverter box and a curtain drain. The diverter box was checked to determine the active line. Two piezometers were installed between 3.5 and $4 \mathrm{ft}$ from an active line. The shallow piezometer was screened from 4 to 8 and the deep piezometer was screened from 12 to $16 \mathrm{ft}$ deep. Water samples for chloride, nutrient, and bacteria analyses were collected from both piezometers the day after installation (table 4). This site was selected for phase 3 work; see "Phase 3 sites" section in the text for more information. The July monthly precipitation at the Xenia, Ohio, station was 6.27 in., 1.65 in. greater than normal; during the two weeks before sampling the precipitation was 1.65 in. (National Oceanic and Atmospheric Administration, 2003a).

GR-751.-Piezometers were installed in late July. The system has two sets of leach lines with a diverter box but no curtain drain. The diverter box was checked to determine the active line. Three piezometers were installed over several 
days and between 3.5 to $4 \mathrm{ft}$ from an active leach line. The first piezometer was set with the screened interval from 0 to $4 \mathrm{ft}$; when checked the next day the piezometer was dry. Two piezometers were then set with screens from 4 to 8 and 12 to $16 \mathrm{ft}$ deep. Water samples for chloride, nutrient, and bacteria analyses were collected from the deep piezometer the day after installation (table 4). The shallow piezometer was dry.

GR-752.-Piezometers were installed in early August.

The system has two sets of leach lines with a diverter box and a curtain drain. The diverter box was checked to determine the active line. Two piezometers were installed between 3.5 and $4 \mathrm{ft}$ from an active line. The shallow piezometer was screened from 4 to 8 and the deep piezometer was screened from 12 to $16 \mathrm{ft}$ deep. Water samples for chloride, nutrient, and bacteria analyses were collected from both piezometers the day after installation (table 4). This site was selected for phase 3 work; see "Phase 3 sites" section in the text for more information.

GR-753.-Piezometers were installed in early August. The system has two sets of leach lines with a diverter box and a curtain drain. The leach field is in a slightly sloping yard. The diverter box was checked to determine the active line. Two piezometers were installed about $4 \mathrm{ft}$ from the lowest (furthest downslope) active leach line. Water samples were collected for chloride, nutrient, and bacteria analyses from both piezometers the day after installation (table 4).

The Hardin County site, $\mathbf{H N} \mathbf{- 1 3 9}$, was in soil region 3, the Blount-Pewamo-Glynwood series (figs. 1, 2) and the Blount-Pewamo soil association. This soil association is described as silt and silty-clay loams with somewhat poor to very poor drainage and slow to moderately slow permeability (Miller and Robbins, 1994). Piezometers were installed in early August. The July monthly precipitation at the Kenton,Ohio, station was 6.85 in., 2.91 in. greater than normal; during the two weeks before sampling the precipitation was 2.51 in. (National Oceanic and Atmospheric Administration, 2003a). The system has two sets of leach lines with a diverter box but no curtain drain. When the diverter box was checked it appeared that both sets of leach lines were active. Three piezometers were installed over several days about $4 \mathrm{ft}$ from an active leach line. The first two piezometers installed were screened from 4 to $8 \mathrm{ft}$ and 12 to $16 \mathrm{ft}$ deep. Water samples for chloride, nutrient and bacteria analyses were collected from the shallow piezometer the day after installation; the deep piezometer was dry (table 4). A second deep piezometer was installed, screened from 18 to $22 \mathrm{ft}$ deep, but no water was obtained from this piezometer either.

The Knox County sites, $\mathbf{K}-\mathbf{1 0}$ and $\mathbf{K}-\mathbf{1 1}$, were in soil region 8, the Westmoreland-Homewood-Loudonville series (figs. 1, 2). Piezometers were installed in late August. The August monthly precipitation at the Greer and Danville, Ohio, stations were 4.31in. and 5.0 in. respectively. The precipitation at the Danville station was 1.16 in. greater than normal (no data was given for the Greer station); during the two weeks before sampling the precipitation was about 1.4 in. at both stations (National Oceanic and Atmospheric Administration, 2003b). The soils at the eastern site, K-10 (fig. 2), were mapped in the Loudonville-Westmoreland-Gilpin association, which is described as being well drained with moderate permeability. These soils are noted as being favorable to home building because of the good drainage; however, bedrock can interfere with the construction of basements and septic systems (Redmond and Graham, 1986). The site had two leach fields, installed on a slope, with a diverter box but no curtain drain. The diverter box was checked, and the active field was the higher one on the slope. The homeowner noted that bedrock was hit during the construction of the basement. Two piezometers, screened from 3 to 7 and 9 to $13 \mathrm{ft}$ deep, were installed about $4 \mathrm{ft}$ upslope (access downslope was limited) from the first active leach line. Water samples for nutrient and bacteria analysis were collected from both piezometers the day after installation (table 4). The soils at the western site, $\mathrm{K}-11$, were mapped in Wooster-Loudonville-Canfield association, which is described as well drained with moderately slow to moderate permeability (Redmond and Graham, 1986). The site had two leach fields with a diverter box but no curtain drain. The diverter box was checked and two piezometers were installed about $4 \mathrm{ft}$ from the ends of the active lines. The piezometers were screened from 4 to 8 and 12 to $16 \mathrm{ft}$ deep. Sampling was attempted the day after installation. Only about $200 \mathrm{~mL}$ was collected from the deep piezometer, enough for bacteria analysis only (table 4 ). The shallow piezometer was dry.

The Licking County site, LI-16, was in soil region 5, the Bennington-Cardington-Centerburg series (figs. 1, 2 ) in the Marengo silty clay loam, which is described as having very slow drainage (Wildermuth and others, 1930). These soils series are formed on glacial tills and ground and end moraines and are somewhat poorly or moderately well drained and have slow to moderately slow permeabilities (McLoda and Parkinson, 1980; Redmond and Graham, 1986). Three piezometers were installed mid-January. The ground was frozen at the time and precipitation in the weeks before was primarily snow (National Oceanic and Atmospheric Administration, 2003f, 2004). The system had a diverter box and curtain drains only along the longest sides of the leach field. The diverter box was checked to determine the active line. Two of the piezometers, a shallow-deep pair, were installed about $4 \mathrm{ft}$ from the end of an active line; a second shallow piezometer was installed between two active lines. The shallow piezometers were screened from 4 to 8 $\mathrm{ft}$ deep; the deep piezometer was screened from 8 to $12 \mathrm{ft}$ deep. Despite freezing in the sampling line, enough water was obtained from each piezometer for chloride, nutrient, and bacteria analyses (table 4). 



8 Printed on recycled paper 